\title{
The comparability of audit reports issued in the European Union: An empirical study based on separate and consolidated financial data
}

\author{
Mondher FAKHFAKH \\ Associate Professor of Accounting, Department of Accounting, \\ Faculty of Economics and Management of Sfax, \\ University of Sfax, \\ Airport Road, 1088, Sfax 3018, Tunisia \\ E-mail: mondher.fakhfakh@laposte.net Contact \# (+216) 95398135
}

Received: November 16, 2012 Accepted: December 10, 2012 DOI: 10.5296/ijafr.v2i2.3017

\begin{abstract}
The purpose of this article is to analyse the degree of European harmonisation of audit reports. This analysis refers to the international auditing standards that have been formally adopted in Europe.

In this article we analysed the wording of audit reports issued in the European Union. This analysis is accompanied by tests that verify the assumptions of homogeneity and comparability of European reports. The interpretation of results is assisted by several statistical techniques including univariate and multivariate tests.

The results show that the objective of the European harmonisation of audit reports is not fully realised. Despite the wealth of information in some reports, European auditors do not always conform to the International Standard on Auditing ISA 700.

This paper includes an empirical analysis on the normative content of audit reports Europe. This analysis refers to international standards that support the performance of audit reports in Europe. In addition to information on the separate financial statements, this article considers, for the first time, the consolidated reports. The author discusses and tests the hypothesis of European harmonisation of audit reports.
\end{abstract}

Keywords: European Union, International Standard on Auditing, Compliance, Audit reports, Harmonisation, Stakeholders 


\section{Introduction}

The European Union (EU) is an economic, political and financial combination of several member states which are located primarily in Europe. The EU traces its origins from the European Coal and Steel Community and the European Economic Community, formed by six countries in 1958. It meets several multinationals and financial markets that are deemed international.

Considering the European multivariate power, the accounting and auditing statements are important in the financial communication and investment decisions. According to the literature, comparability (as a corollary of harmonisation) and reliability of audit reports are two qualitative characteristics which enhance the performance of financial communications. These characteristics improve the understandability of the accounting publications and the auditing reports.

According to the Generally Accepted Auditing Standards (GAAS), the audit report is a tool of financial communication and an internal management tool. It communicates to users of separate and consolidated financial statements (Shareholders, managers, customers, suppliers, researchers, financial analysts ...) an independent opinion on the accuracy of accounting information.

The International Federation of Accountants (IFAC) and the financial authorities of the European Union played a fundamental role in the harmonisation of audit and the accounting rules governing the external control. Their mission is to support the development of the accounting profession, which proposes the uniform services and high quality, in the interest of the public. Its achievements cover a series of standards and directives intended for a population of Certified Public Accountants dispersed in the whole world.

In terms of financial communication, the International Federation of Accountants has published an international standard (ISA700) which defines the components of audit reports. After several works of consultation, the European institutions have officially adopted the ISA700 in order to improve the quality of auditing communication.

Under the adoption choice of ISA700, it is relevant to wonder about the harmonisation level of the audit reports published in EU. Within this same framework, it seems interesting to raise the question about the contributions of the revised standard (ISA700) for the European community of accountants. More particularly, to which level does the revised ISA700 contribute to the improvement of the informative content and the comparability of the European audit reports?

\section{The research of the harmonisation of audit reports within the European Union}

The term "Harmonisation" was the subject of several definitions suggested by research specifying the aims of the accountancy harmonisation. It indicates a process followed to increase the comparability of the accounting practices, limit their levels of variability (Nobes and Parker, 2000) and facilitate the comparison of the financial statements of the different domestic corporations (Colasse, 2001).

The harmonisation of auditing reports is identified as the process which aims the reduction of the audit practices diversity and to ensure their uniformity and their convergence in matter of the audit communicative supports. It aims to minimise the divergences between the 
normative national regulations which govern the communications between the auditors and other Stakeholders.

The mission of auditing harmonisation is the work of supranational organisations. These organisations follow a process which aims an alignment of the currents audit practices and to limit any total standardisation, rigid and absolute of the existing revision rules.

The accounting literature enumerates several arguments in favour of the harmonisation of the audit reports. According to Gangolly et al. (2002), the importance of the auditing harmonisation is apprehended through the reduction of informational asymmetry, the reduction of the costs of information search and the costs of the standards development.

\subsection{The reduction of costs related to the search of financial information}

The apprehension of the auditing harmonisation interest and its role, which can reduce the costs of obtaining data, entails a climate of informational asymmetry between several users of the financial statements. This asymmetry is accentuated between the partners of the multinationals whose levels of knowledge vary significantly.

The audit harmonisation, including the letters and accountants reports, offers a common repertoire and uniform reference to all the local accountants. It allows the possibility to confine audit information in comprehensible messages addressed to various partners worldwide. Such intelligibility could facilitate a quick reception of information about the results of revision from the subsidiary companies. It also allows minimising:

- the costs of research and analysis of accounting data

- investments and efforts made to interpret the conclusions drawn on the work control

- the additional engagement of energy for decoding messages

- the financing load in the collection of information

- time to get indicators.

\subsection{The improvement of comparability of financial information}

Regarding the financial communication through the audit reports, it is generally accepted that satisfying the Stakeholders' needs depends on several qualitative characteristics such as: reliability, punctuality, comparability and intelligibility. The absence of these characteristics is likely to intensify the Gap between standards, expectations and accounting practices.

Comparability of audited information is important for many European users of financial statements and more particularly for the investors. Several European conceptual framework identify (comparability) as an enhancing qualitative characteristic of financial statements. Specifically, users must be able to compare the audited information and audit reports of different entities in order to evaluate their relative financial positions, performance and changes in financial position.

\section{The normative framework of audit reports on financial statements prepared within the European Union}

To the European scale, the Ministers Council leads the process of statutory audit harmonisation. It is supported by other institutions having specific roles and missions, which are complementary for the organisation of the performance of the statutory audit of the 


\section{Mll Macrothink}

International Journal of Accounting and Financial Reporting ISSN 2162-3082 2012, Vol. 2, No. 2

accounts (European Commission and Committee of European audit). In accordance with the Rome Treaty, this council is equipped with the capacity to take measures concerning the fields which are not covered by the European Commission competence. It manages a mechanism of legal harmonisation which performs the legal directives that the Member States must apply.

The execution of the programme of European harmonisation of audit was accompanied by the publication of several documents. These publications, covering the directives and the green book, bore interest to the audit reports and the general framework of their emission. The published European directives were gradually integrated into the company law and the accounting regulation of the States of the EU (Brandao, 1997).

\subsection{The contribution of the European directives}

In order to harmonise accounting practices and audit, the institutions of the European Union have issued three directives (Fourth, Seventh and Eighth directives). A directive is a legislative act of the European Union which requires member states to achieve a particular result without dictating the means of achieving that result. It can be distinguished from regulations which are self-executing and do not require any implementing measures. Directives normally leave member states with a certain amount of leeway as to the exact rules to be adopted. Directives can be adopted by means of a variety of legislative procedures depending on their subject matter.

According to Botez and Pravat (2009), the Fourth Directive is based on the article No. 53 of The Treaty from Rome, being a compromise of this type of financial reporting legislation and the approach is based on the trusty image concept. This accounting directive offers the possibility of choice between more accountant alternatives of solving different problems and offers options to member states in what its application is concerned.

The Directive covers public and private companies in all EU countries. Its articles include those referring to valuation rules, format of published financial statements and disclosure requirements.

The fourth Directive's first draft was published in 1971, before the United Kingdom, Ireland and Denmark had entered the EU in 1973. This initial draft was heavily influenced by German company law. Consequently, valuation rules were conservative, formats were prescribed in rigid detail, and disclosure by notes was very limited.

The Seventh European Directive on Company Law coordinates national laws on consolidated accounts of companies with limited liability. It belongs to the family of "accounting directives" that form the arsenal of Community legal acts governing company accounts.

The Seventh Directive defines the circumstances in which consolidated accounts are to be drawn up. It sets out the methods of drawing up consolidated accounts. The same european document establish a system of auditing under which a company which prepares consolidated accounts must have them audited by one or more persons authorised to audit accounts under the laws of the Member State which govern that company. The person or persons responsible for auditing the consolidated accounts must also verify that the consolidated annual report is consistent with the consolidated accounts for the same financial year.

The eighth Directive (which dates from the year 1984) was issued in order to complete the 


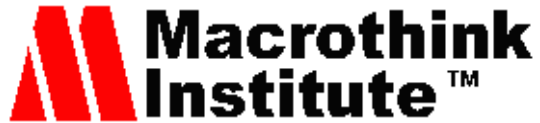

International Journal of Accounting and Financial Reporting

series of Directives concerning company accounts, defining the qualifications of persons responsible for carrying out the statutory audits of the accounting documents required by the fourth and seventh Directives. This Directive applies to persons responsible for carrying out:

- statutory audits of the annual accounts of companies and firms and verifying that the annual reports are consistent with those annual accounts in so far as such audits and such verification are required by Community law;

- statutory audits of the consolidated accounts of bodies of undertakings and verifying that the consolidated annual reports are consistent with those consolidated accounts in so far as such audits and such verification are required by Community law.

\subsection{The contribution of the green paper}

In 1996, the commission of the European communities has published an important document for the strengthening of the comparability of accounting practices in Europe. This publication entitled (Green paper) focused on the role, status and responsibility of the statutory auditor within the European Union. It is composed of eight parts which discuss:

- The regulation of statutory audit at eu level and need for eu action;

- The role of the statutory auditor;

- The position of the statutory auditor;

- The auditor's civil liability;

- The statutory audit in small companies;

- The group audit arrangements;

- The freedom of establishment and the freedom to provide services.

According to the green book, the audit report is the medium through which the statutory auditor communicates with shareholders, creditors, employees and with the public at large. It is the result of the audit process.

The paragraphe $\mathrm{N}^{\circ} 3.41$ states that in general, the audit report concerning the annual accounts in Member States would normally contain the following information:

- Whether the auditor has obtained all the information and explanations which, to the best of his knowledge and belief, are necessary for the purposes of his audit;

- Whether, in his opinion, proper books and records have been kept by the company;

- Whether the annual report is consistent with the annual accounts;

- Whether the annual accounts give a true and fair view of the company's assets, liabilities, financial position and profit or loss;

- Whether the annual accounts comply with the requirements of company law;

- Whether the audit was carried out in accordance with auditing standards.

\subsection{The adoption of the International Standards on Auditing $N^{\circ} 700$}

The new Audit Directive of 17th May 2006 enforces the use of "International Standards on Auditing" (ISAs) for all statutory audit to be performed in the EU. Aiming at a consistently high quality for all statutory audits required by Community law, the Audit Directive has given implementing powers to the European Commission (EC) to adopt the ISAs in accordance 


\section{MInstitute Macrothink $^{m}$}

International Journal of Accounting and Financial Reporting

with the so-called "Comitology procedure" (Schockaert and and Houyoux, 2007).

The International Federation of Accountants (IFAC) currently gathers national professional organisations of accounting experts and rests on other regional organisations. It was founded in October 1977 following an agreement signed by 63 accounting organisations which represent 49 countries. Its objective is to develop and reinforce the profession of accountants with harmonised standards. To achieve this goal, the council of the International Federation of Accountants constituted the International Committee of the Practices of Audit. This Committee was replaced by the Institute of Auditing and Assurance Standards Board.

The efforts made in the international harmonisation of the audit report and which have lead to the publication of the international standard (ISA 700, previously IAG 13) make testimony of the efforts made for the achievement of an international consensus of the auditing opinion.

The international standard of auditor's report initially appeared in October 1983 in the form of an international recommendation for audit (IAG13). Its objective was to bring recommendations to the model of auditing opinion. Its publication aimed at harmonising the audit approach and setting a common reference for accountants' work.

After several years of changes and improvement, International Guideline 13 was transformed into the standard ISA700 "The Auditor's Report on Financial Statements". On the basis of inspiration from the professional organisations' proposals and of their members, The IFAC proceeded to a basic revision of the textual elements of its standardised report. This reform was not separately introduced from the reinforcement of the informational value allotted to the accountant's report.

The last revision of the wording of the international auditing report shows several innovative aspects of the international standardisation approach. Such innovation is the result of the interaction of several accounting cultures represented at the council of the international Federation of the accountants.

The revision of the ISA700 by the IAASB was carried out in order to increase the transparency and the auditors' reports comparability on an international scale. It follows a series of changes brought to the standards on auditor's report.

The arrangements resulting from the standard ISA700 revision apply to the auditor's reports delivered after the December 31, 2006. They modify the content of the accountant's report in order to better explain the role of audit to the financial statements readers.

The wording suggested by the revised auditor's report takes into consideration the new standards of the audit mission risk. It is composed of 38 elements of form (Title, Addressee, Auditor's Signature, Date of the Auditor's Report and Auditor's Address) and content (Introductory paragraph, management's responsibility for the financial statements, auditor's responsibility, auditor's opinion and other reporting responsibilities).

The new arrangements resulting from the wording extension describe the respective responsibilities of management and auditor in detail. They report the accounting control process with more precision and inform on the extent of the professional responsibilities of the internal control system (Appendix 1). 


\section{Previous studies on the European harmonisation of auditor's report}

\section{The European harmonisation of national standards on auditor's report}

In the 1998 European Federation of Accountants (FEE) has published a document entitled: Setting the Standards Statutory Audit in Europe. This publication contains a study which compared national auditing standards in Europe with International Standards on Auditing (ISA).

The comparative study concludes that European national standards are substantially in line with International Standards on Auditing (ISA). According to the FEE's report issued in June 1998, the correlation between national standards and ISA demonstrates the strength of co-operation between professional bodies on an international basis, a co-operation developed through the processes of self-regulation. It provides confidence of a "platform" of a consistent audit approach throughout Europe.

Given the increasing importance of the auditor's report in a worldwide market place, FEE decided to produce a further survey in 2000 « The Auditor's Report in Europe ». This survey summarises an in depth study comparing the structure and detailed content of the national Auditors' reports across Europe to the International Auditing Standard ISA 700 (The auditor's report on financial statements). In this survey, FEE presented an overview of national standard setting for Auditors' reports and examples of Unmodified Auditor's Report by country.

The FEE's Survey (2000) showed that there was considerable variation in the wordings of statutory auditors' reports between EU member states. The variations were caused in part by differences in auditing standards (relatively minor differences in standards are neither transparent nor clearly identifiable) and, more significantly, by differences in national laws and regulations governing the subject matter and form of auditors' reports. This is an obstacle to the development of a single internal market in audit services.

\subsection{The European harmonisation of national practices on auditor's report}

There are several studies which analyse whether European auditors, who are members of the IFAC council, follow the ISA700 when they prepare the audit report (Archer et al., 1989; King, 1999; Wallage, 1993; Garcia-Benau and Zorio, 2004).

Archer et al. (1989) examined 206 audit reports of European multinational firms. These authors adopted a comparative approach, which was based on the IAG13. The results found by Archer et al. (1989) detected harmonisation in auditing reports practices among European countries. The reports published in France, the UK and Holland were in perfect conformity with the international reference.

Additionally, King (1999) tried to measure the harmonisation in the form and content of the auditor's report in the European Union. To realise this goal, audit reports from 1995 annual reports of the largest industrial companies in Austria, Belgium, Denmark, Finland, France, Germany, Ireland, Italy, Netherlands, Portugal, Spain, Sweden and the UK were analysed. The analysis uses the basic elements of the auditor's report listed in the ISA700 (IFAC, 1994). Comparability is tested using the chi-square statistic, which tests for equality of the proportions of the various elements in the auditor's report across the member states. The results reveal that harmonisation exists in three of the five elements in the auditor report 
relating to form (appropriate title, the dating of the report and the listing of the location of the auditor's office). Harmonisation does not exist for the remaining two elements related to form, nor does it exist for any of the elements related to content.

Wallage (1993) described the auditing approaches of the big accounting firms located in the Netherlands (The International Affiliation of Independent Accountants, Dunwoody Robson McGladrey \& Pullen, Coopers and Lybrand, Ernest and Whinney, BDO, KPMG, Arthur Young, Moores and Rowland Int., Price Waterhouse, Touch Ross Int., Deloite Haskins and Sells, Horwarth and Horwarth Int.). The objective of his study was to determine the level of the international guidelines of auditing. The author followed the same methodology used by Cushing and Loebbecke (1986). Wallage (1993)'s paper is based on the examination of auditing documents of the large accounting firms. The results divided the big firms observed into three groups:

- the first group (A) includes accounting firms whose auditing approaches are influenced by IFAC international guidelines of auditing

- the second group (B) is composed of the big firms that simultaneously apply Netherlands and international guidelines

- the third group (C) is formed of accounting firms that apply only the auditing guidelines of Netherlands.

Thus, the results show that the first group considers the elements of IAG13. Regarding the second group, only $46 \%$ of the firms observed are in total compliance with IFAC audit report guideline. For the third group, $75 \%$ of accounting firms do not rigorously apply the elements provided by IFAC.

Garcia-Benau and Zorio (2004) examined the audit report of 147 firms from the European Union that prepare their financial statements in compliance with the standards developed by the International Accounting Standards Board. Interesting conclusions are drawn from this research with regard to the auditing standards applied, the wording used and the differences observed between reports produced by auditors from the big firms and reports from different European countries.

Regarding the hypotheses formulated by the authors, the results of the study show that:

- There is no link between whether the company has been audited by a Big 5 firm or not and the audit standards followed, according to the auditor's report.

- Any Big 5 firm is equally prone to audit financial statements according to local GAAS, ISAs or both.

- There is a link between the country of origin for the company (i.e. Austria, Germany or 'other countries'), and the audit standards followed, according to the auditor's report.

- There is no link between the sector9 of the company, and the audit standards followed, according to the auditor's report.

- There is a link between whether the company has been audited by a Big 5 firm or not and the framework used in the preparation of financial statements according to the statement made in the audit report.

- Any Big 5 firm is equally prone to audit financial statements according to the statement 


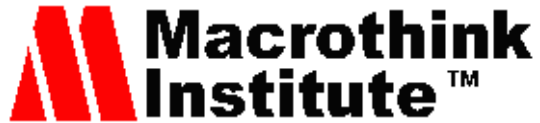

International Journal of Accounting and Financial Reporting ISSN 2162-3082

made in the audit report on whether the company has followed either local GAAP, IAS or both.

- There is a link between the country of origin of the company (i.e. Austria, Germany or 'other countries'), and whether the auditor's opinion is worded in terms of the 'true and fair view' or the 'present fairly' phraseology.

- There is no link between the sector of the company, and whether the auditor's opinion is worded in terms of the 'true and fair view' or the 'present fairly' phraseology.

Beyond the presentation of the literature review, it is important to mention the limitations of previous research. The review of previous research shows that consolidated audit reports were not considered in studies of European harmonisation of audit reports. The results of this research seem to be reducing and not conducive to reliable measure of accounting harmonisation.

The consolidated financial information (financial statements and audit reports of groups of companies) are in great demand in the European Union. The importance of the application of this information is enhanced by the enactment of several laws and guidelines.

The inattention paid to consolidated information weakens the relevance of empirical studies. The absence of consolidated data reduces the severity of Accounting Research and down the significance of the samples.

In contrast to research on the harmonisation of financial accounting, the accounting literature does not provide indexes that model the phenomena of harmonisation of audit practices. The study of these phenomena deserves mathematical modeling of auditing practices and the identification of factors that influence the behavior of the independent auditors.

Remaining in the empirical accounting research, the literature review shows the inapplicability of multivariate tools. The application of univariate tests only does not refine the statistical analyses and weakens the interpretation of results.

\section{The informational content of the European auditors' reports}

The analysis of the content of audit reports enumerates the principles followed by the independent auditors and measures the degree of conformity to the accounting standards. The analytical examination of the current structure of the European auditing report can inform on the progress of the IFAC's harmonisation and the new challenge of the uniformity of the accounting rules. This harmonisation may face many obstacles and require several adaptations in different contexts.

\subsection{The methodology of research}

The methodology used in the analysis of European audit report practices and the empirical study of the reports' informative content consists of a comparative examination based on the wording of revised ISA700 to locate the elements that contribute to the reinforcement of the audit informational value, the improvement of practices followed by the statutory auditors, and the homogeneity of the principles retained for the presentation of the audit results.

\subsubsection{The observed data}

The choice of the period of study is guided by the Revised ISA 700 principles, which indicate that the revised standard report is applied for audited financial statements established 


\section{Al Macrothink}

International Journal of Accounting and Financial Reporting

ISSN 2162-3082

2012, Vol. 2, No. 2

subsequently to 31 December 2006. The studied sample is composed of 221 auditing reports signed during three years (2007, 2008 and 2009) by certified public accountants from 27 countries. The table (1) describes the composition of the selected sample.

The selection of data is based on the stratified sampling method. This statistical technique is applied when the population embraces a number of distinct categories, which are identified as separate 'strata'. Each stratum is then sampled as an independent subpopulation, out of which individual elements can be randomly selected (Pedhazur and Schmelkin, 1991).

For the current article, the strata represent the 27 countries taken for the study of the accounting harmonisation phenomenon. For every country, the selection of auditor's report is based on simple random sampling. Each element of the frame thus has an equal probability of selection: the frame is not subdivided or partitioned. This minimises bias and simplifies analysis of results. In particular, the variance between individual results within the sample is a good indicator of variance in the overall population, which makes it relatively easy to estimate the accuracy of results.

The most of the observations are extracted from the accounting reports of international firms and from the documentation provided by the regulation authorities. Other supplementary information sources were consulted to maintain the representativeness of the study sample (financial bulletins, internet websites, and economic newspapers).

The number of reports for every stratum is influenced by the availability of published financial data. Translation work was imposed on several French reports in order to ensure a common background for the sake of the comparison of the audit terminology. 
Table 1. The sample of the study

\begin{tabular}{|c|c|c|c|c|}
\hline \multirow{2}{*}{\multicolumn{2}{|c|}{$\begin{array}{c}\text { Countries of } \\
\text { European Union }\end{array}$}} & \multirow{3}{*}{$\begin{array}{c}\text { Number of } \\
\text { reports }\end{array}$} & \multicolumn{2}{|c|}{ Auditors' reports } \\
\hline & & & \multirow{2}{*}{$\begin{array}{c}\text { On separate financial } \\
\text { statements }\end{array}$} & \multirow{2}{*}{$\begin{array}{c}\begin{array}{c}\text { On consolidated } \\
\text { financial statements }\end{array} \\
12\end{array}$} \\
\hline 1 & Austria & & & \\
\hline 2 & Belgium & 12 & 10 & 2 \\
\hline 3 & Bulgaria & 8 & 5 & 3 \\
\hline 4 & Cyprus & 8 & 2 & 6 \\
\hline 5 & Czech Republic & 8 & 7 & 1 \\
\hline 6 & Denmark & 8 & 3 & 5 \\
\hline 7 & Estonia & 6 & 1 & 5 \\
\hline 8 & Finland & 5 & 1 & 4 \\
\hline 9 & France & 16 & 12 & 4 \\
\hline 10 & Germany & 10 & 3 & 7 \\
\hline 11 & Greece & 7 & 4 & 3 \\
\hline 12 & Hungary & 7 & 3 & 4 \\
\hline 13 & Ireland & 6 & 3 & 3 \\
\hline 14 & Italy & 7 & 1 & 6 \\
\hline 15 & Latvia & 6 & 3 & 3 \\
\hline 16 & Lithuania & 12 & 4 & 8 \\
\hline 17 & Luxembourg & 6 & 5 & 1 \\
\hline 18 & Malta & 9 & 7 & 2 \\
\hline 19 & Poland & 7 & 4 & 3 \\
\hline 20 & Portugal & 4 & 2 & 2 \\
\hline 21 & Romania & 6 & 2 & 4 \\
\hline 22 & Slovakia & 3 & 2 & 1 \\
\hline 23 & Slovenia & 4 & 3 & 1 \\
\hline 24 & Spain & 7 & 1 & 6 \\
\hline 25 & Sweden & 18 & 9 & 9 \\
\hline 26 & The Netherlands & 4 & 2 & 2 \\
\hline 27 & UK & 14 & 5 & 9 \\
\hline & Total & 221 & 105 & 116 \\
\hline
\end{tabular}

\subsubsection{The Statistical analysis of the wording of the European auditor's reports}

This study of the potentiality of information in European audit reports needs to consider the current level of conformity to the arrangements established in the revised international standard on audit reports. To achieve, a comparison with international auditing doctrine was performed, based on a selection of basic elements of the audit report prepared according to the International Standard on Auditing. All these elements are summarised by a score of 38 


\section{Al Macrothink}

International Journal of Accounting and Financial Reporting

ISSN 2162-3082

2012, Vol. 2, No. 2

points indicating the form and the content of the independent auditor's report (Table 2).

The analysis of the data related to the content of European auditor's reports is assisted by univariate and multivariate tests. The univariate analyses include the One-Sample Test for the comparison of means. This parametric test is adopted when the examination aims to determine if the expectation of a given sample (theoretical mean) is significantly different from a reference value.

The multivariate analyses include several parametrics tests which based on the comparison of the variances and the average scores. The Chi-square test (as non parametric test) is used for the comparison of several proportions.

Table 2. Normative scores recommended by the Revised ISA 700

\begin{tabular}{|l|c|c|}
\hline \multicolumn{1}{|c|}{ Elements } & Partial scores & Global score \\
\hline Title & 1 \\
\hline Addressee & 1 \\
\hline & 7 \\
\hline $\begin{array}{l}\text { Management's responsibility for } \\
\text { the financial statements }\end{array}$ & 8 \\
\hline Auditor's responsibility & 14 \\
\hline Auditor's opinion & 3 \\
\hline Other reporting responsibilities & 1 \\
\hline Auditor's Signature & 1 \\
\hline Date of the Auditor's Report & 1 \\
\hline Auditor's Address & 1 \\
\hline
\end{tabular}

\subsection{The empirical results}

5.2.1. The content of the European audit reports (Analysis under the wording of the revised ISA 700)

In terms of the whole normative arrangements envisaged by the revised ISA 700, the conclusions of this study do not confirm the perfect application of the international principles exhaustiveness (Table 3). The empirical results stress that the total observed scores are statistically different from the score recommended by the revised ISA700 (38). The lack of respect of ISA 700R limits the relevance of the financial communication between the certified accountants and Stakeholders. 


\section{Macrothink}

Table 3. One-sample test for all elements of the audit reports prepared according to the ISA 700 (Auditors' reports on consolidated financial statements/ Auditors' reports on separate financial statements)

\begin{tabular}{|l|c|c|c|}
\hline & $\begin{array}{c}\text { Consolidated and separate } \\
\text { audit reports }\end{array}$ & Separate reports & Consolidated reports \\
\hline Test value & 38.000 & 38.000 & 38.000 \\
\hline $\mathrm{T}$ (observed value) & -15.893 & -10.981 & -11.446 \\
\hline $\mathrm{T}$ (critical value) & 1.971 & 1.983 & 1.981 \\
\hline $\mathrm{df}$ & 220.000 & 104.000 & 115.000 \\
\hline Sig (two-tailed) & $<0.0001$ & $<0.0001$ & $<0.0001$ \\
\hline
\end{tabular}

For auditor's reports on consolidated financial statements, the descriptive statistics show that the accounting reports published in four countries (Greece, Lithuania, Luxembourg and Poland) reflect the highest conformity level to the international principles on audit reports (average score of conformity 38). Within the same line of high compliance with revised ISA 700, it is necessary to consider the auditing reports published in Czech Republic, Estonia, Malta, Slovakia, Slovenia, The Netherlands, Romania and Latvia. The Finnish auditors' reports do not include several international normative elements and are attributed the average score of the lowest conformity. Other national annual reports published by accounting firms in the France, Germany, UK, Ireland, Sweden, Spain, Portugal, Italy record the same weakness of conformity level (Table 4.1).

For auditor's reports on separate financial statements, the statistics show that the accounting reports published in five countries (Luxembourg, Slovenia, Latvia, Czech Republic and Bulgaria) reflect the highest conformity level to the international principles on audit reports. Other national annual reports published by accounting firms in the Germany, Spain, Hungary, Sweden, Italy, Belgium, Cyprus and Portugal record the same weakness of conformity level (Table 4.2). 


\section{Macrothink \\ International Journal of Accounting and Financial Reporting ISSN 2162-3082 2012, Vol. 2, No. 2}

Table 4. Descriptive statistics (European compliance with full element of the Revised ISA 700)

\begin{tabular}{|l|c|c|c|c|c|c|}
\hline $\begin{array}{c}\text { Countries of } \\
\text { European } \\
\text { Union }\end{array}$ & \multicolumn{2}{|c|}{$\begin{array}{c}\text { Table 4.1. Auditor's reports on } \\
\text { consolidated financial statements }\end{array}$} & \multicolumn{2}{c|}{$\begin{array}{c}\text { Table 4.2. Auditor's reports on } \\
\text { separate financial statements }\end{array}$} \\
\cline { 2 - 7 } & Mean & Min & Max & Mean & Min & Max \\
\hline Austria & 32.083 & 19 & 36 & 37 & 37 & 37 \\
\hline Belgium & 36.50 & 36 & 37 & 30 & 26 & 34 \\
\hline Bulgaria & 34.33 & 31 & 38 & 37.4 & 36 & 38 \\
\hline Cyprus & 36.833 & 36 & 38 & 30 & 24 & 36 \\
\hline Czech & 37 & 37 & 37 & 36.714 & 35 & 38 \\
Republic & & & & & & \\
\hline Denmark & 33.800 & 33 & 35 & 34 & 33 & 35 \\
\hline Estonia & 37 & 37 & 37 & 37 & 37 & 37 \\
\hline Finland & 19.25 & 13 & 22 & 37 & 37 & 37 \\
\hline France & 19.75 & 17 & 23 & 18.917 & 17 & 23 \\
\hline Germany & 21.143 & 20 & 22 & 21 & 21 & 21 \\
\hline Greece & 38 & 38 & 38 & 37 & 35 & 38 \\
\hline Hungary & 35.50 & 34 & 37 & 23 & 9 & 37 \\
\hline Ireland & 23 & 23 & 23 & 21.667 & 19 & 23 \\
\hline Italy & 25.167 & 25 & 26 & 25 & 25 & 25 \\
\hline Latvia & 37.667 & 37 & 38 & 36.667 & 36 & 37 \\
\hline Lithuania & 38 & 38 & 38 & 37 & 37 & 37 \\
\hline Luxembourg & 38 & 38 & 38 & 36.200 & 33 & 38 \\
\hline Malta & 37 & 36 & 38 & 32.714 & 20 & 38 \\
\hline Poland & 38 & 38 & 38 & 35 & 26 & 38 \\
\hline Portugal & 25 & 24 & 26 & 30 & 23 & 37 \\
\hline Romania & 37.250 & 36 & 38 & 31 & 24 & 38 \\
\hline Slovakia & 37 & 37 & 37 & 30.50 & 24 & 37 \\
\hline Slovenia & 37 & 37 & 37 & 36.333 & 36 & 37 \\
\hline Spain & 23.167 & 21 & 25 & 21 & 21 & 21 \\
\hline Sweden & 23 & 23 & 23 & 23 & 23 & 23 \\
\hline The & 37 & 37 & 37 & 35 & 34 & 36 \\
\hline Netherlands & 22.667 & 19 & 25 & 23.200 & 19 & 25 \\
\hline UK & & & & & & \\
\hline
\end{tabular}

Pre-/post-Revised ISA 700 differences in Europran conformity with Revised ISA 700

The impact discussion of the innovations and changes on the improvement of IFAC's harmonisation of European auditor's report (on consolidated and separate financial statements) encourages the accounting researcher to analyse the differences between 
conformity levels with the international standard for the pre- and post-Revised ISA 700 regime. The study of these differences tests the null hypothesis of no difference between the total scores of the two regimes using the Chi-square test for several proportions. For the pre-revised ISA 700 regime, the investigated data is inspired of the information, which were observed by previous researches of King (1999).

In sum, the investigation of the reports revealed that the comparison of the pre- and post Revised ISA 700 regimes shows a statistically significant difference. It has also been shown that the hypothesis that state on the proportions equality is to be rejected (Table 5). As it can be seen from the computed percentage of conformity, post-Revised ISA 700 scores are lower than the pre-Revised ISA 700 scores. The same result of conformity is justified by the marginal statistical analyses of the auditors'reports on consolidated and separate financial statements.

Table 5. Pre-/post-Revised ISA 700 differences in compliance with Revised ISA 700 (reports on consolidated and separate financial statements)

\begin{tabular}{|c|c|c|c|c|c|}
\hline \multicolumn{6}{|c|}{ Chi-square statistic tests for the equality of proportions (Conditional analysis) } \\
\hline & $\begin{array}{c}\text { Accounting regime } \\
\text { for European } \\
\text { Union }\end{array}$ & & Non-compliance & $\begin{array}{c}\text { Bidimensional } \\
\text { Chi-square } \\
\text { (critical value) }\end{array}$ & $\begin{array}{c}\text { Multidimensional } \\
\text { Chi-square } \\
\text { (critical value) }\end{array}$ \\
\hline \multirow[t]{3}{*}{ Consolidated } & Pre-Revised & 259 & 145 & \multirow{3}{*}{$\begin{array}{l}71.196 \\
(3.841)\end{array}$} & \multirow{6}{*}{$\begin{array}{c}(160.819) \\
(5.991)\end{array}$} \\
\hline & 700 & & & & \\
\hline & \begin{tabular}{|l|} 
Post-Revised ISA \\
700
\end{tabular} & 23 & 93 & & \\
\hline \multirow[t]{3}{*}{ Separate } & Pre-Revised & 259 & 145 & \multirow{3}{*}{$\begin{array}{l}89.623 \\
(3.841)\end{array}$} & \\
\hline & 700 & & & & \\
\hline & $\begin{array}{l}\text { Post-Revised ISA } \\
700\end{array}$ & 13 & 92 & & \\
\hline \multicolumn{6}{|c|}{ Chi-square statistic tests for the equality of proportions (Marginal analysis) } \\
\hline & $\begin{array}{c}\text { Accounting regime } \\
\text { for European } \\
\text { Union }\end{array}$ & & Non-compliance & \multicolumn{2}{|c|}{$\begin{array}{l}\text { Bidimensional Chi-square } \\
\text { (critical value) }\end{array}$} \\
\hline \multirow{3}{*}{$\begin{array}{l}\text { Consolidated } \\
\text { and separate }\end{array}$} & Pre-Revised & 259 & 145 & \multirow{3}{*}{\multicolumn{2}{|c|}{$\begin{array}{l}131.076 \\
(3.841)\end{array}$}} \\
\hline & 700 & & & & \\
\hline & $\begin{array}{l}\text { Post-Revised ISA } \\
700\end{array}$ & 36 & 185 & & \\
\hline
\end{tabular}

The requirements of the wording of the audit report on consolidated and separate financial $\underline{\text { statements }}$

In terms of form, some normative elements are not retained in the presentation of the European audit reports. The statistical results for reports on separate financial statements 


\section{I Macrothink}

International Journal of Accounting and Financial Reporting

ISSN 2162-3082

2012, Vol. 2, No. 2

show a significant difference between the normative scores and the average of observed scores related to the addressee, the introductory paragraph, the management's responsibility, the auditor's responsibility, the other reporting responsibilities, the date of the auditor's report and the auditor's address (Table 6). The same result (except the elements related to the title, to the auditor's opinion, the auditor's signature and the date of report), is recorded for other reports on consolidated accounting statements (Table 6). Consequently, the absence of several elements recommended by the revised ISA 700 reduces the perfect presentation of the auditing results.

Table 6. One-sample test for elements of the European audit reports prepared according to the Revised ISA 700 (audit reports on consolidated and separate financial statements)

\begin{tabular}{|c|c|c|c|}
\hline \multicolumn{4}{|c|}{ he title (Test value $=1$ ) } \\
\hline & Consolidated and separate reports & Separate reports & Consolidated reports \\
\hline T (observed value) & -1.000 & -1.000 & -1.000 \\
\hline T (critical value) & 1.971 & 1.983 & 1.981 \\
\hline Sig (two-tailed) & 0.318 & 0.320 & 0.319 \\
\hline \multicolumn{4}{|c|}{ Second element related to the addressee (Test value $=1)$} \\
\hline & Consolidated and separate reports & Separate reports & Consolidated reports \\
\hline T (observed value) & -7.396 & -5.250 & -5.188 \\
\hline$T$ (critical value) & 1.971 & 1.983 & 1.981 \\
\hline Sig (two-tailed) & $<0,0001$ & $<0,0001$ & $<0,0001$ \\
\hline \multicolumn{4}{|c|}{ Third element related to the introductory paragraph $($ Test value $=7)$} \\
\hline & Consolidated and separate reports & Separate reports & Consolidated reports \\
\hline T (observed value) & -13.739 & -10.172 & $-9,356$ \\
\hline$T$ (critical value) & 1.971 & 1.983 & 1.981 \\
\hline Sig (two-tailed) & $<0,0001$ & $<0,0001$ & $<0,0001$ \\
\hline \multicolumn{4}{|c|}{$\begin{array}{l}\text { Fourth element related to the management's responsibility for the financial statements (Test } \\
\text { value=8) }\end{array}$} \\
\hline & Consolidated and separate reports & Separate reports & Consolidated reports \\
\hline T (observed value) & -13.068 & -8.592 & -9.836 \\
\hline$T$ (critical value) & 1.971 & 1.983 & 1.981 \\
\hline Sig (two-tailed) & $<0,0001$ & $<0,0001$ & $<0,0001$ \\
\hline \multicolumn{4}{|c|}{ Fifth element related to the auditor's responsibility (Test value $=14$ ) } \\
\hline & Consolidated and separate reports & Separate reports & Consolidated reports \\
\hline T (observed value) & -12.108 & -8.229 & $-8,848$ \\
\hline $\mathrm{T}$ (critical value) & 1.971 & 1.983 & 1.981 \\
\hline Sig (two-tailed) & $<0,0001$ & $<0,0001$ & $<0,0001$ \\
\hline \multicolumn{4}{|c|}{ Sixth element related to the auditor's opinion (Test value $=3$ ) } \\
\hline & Consolidated and separate reports & Separate reports & Consolidated reports \\
\hline
\end{tabular}




\begin{tabular}{|c|c|c|c|}
\hline T (observed value) & -2.635 & -1.968 & -1.747 \\
\hline T (critical value) & 1.971 & 1.983 & 1.981 \\
\hline Sig (two-tailed) & $<0,0001$ & 0.052 & 0.083 \\
\hline \multicolumn{4}{|c|}{ Seventh element related to the other reporting responsibilities (Test value=1) } \\
\hline & Consolidated and separate reports & Separate reports & Consolidated reports \\
\hline $\mathrm{T}$ (observed value) & -10.954 & -8.327 & -7.194 \\
\hline$T$ (critical value) & 1.971 & 1.983 & 1.981 \\
\hline Sig (two-tailed) & $<0,0001$ & $<0,0001$ & $<0,0001$ \\
\hline \multicolumn{4}{|c|}{ Eighth element related to the auditor's signature (Test value $=1$ ) } \\
\hline & Consolidated and separate reports & Separate reports & Consolidated reports \\
\hline T (observed value) & -1.417 & -1.000 & -1.420 \\
\hline T (critical value) & 1.971 & 1.983 & 1.981 \\
\hline Sig (two-tailed) & 0.158 & 0.320 & 0.158 \\
\hline \multicolumn{4}{|c|}{ Ninth element related to the date of the auditor's report (Test value $=1$ ) } \\
\hline & Consolidated and separate reports & Separate reports & Consolidated reports \\
\hline $\mathrm{T}$ (observed value) & -2.875 & -2.511 & -1.420 \\
\hline$T$ (critical value) & 1.971 & 1.983 & 1.981 \\
\hline Sig (two-tailed) & $<0,004$ & 0.014 & 0.158 \\
\hline \multicolumn{4}{|c|}{ Tenth element related to the auditor's address (Test value $=1$ ) } \\
\hline & Consolidated and separate reports & Separate reports & Consolidated reports \\
\hline $\mathrm{T}$ (observed value) & -16.617 & -10.902 & $-12,540$ \\
\hline $\mathrm{T}$ (critical value) & 1.971 & 1.983 & 1.981 \\
\hline Sig (two-tailed) & $<0,0001$ & $<0,0001$ & $<0,0001$ \\
\hline
\end{tabular}

The whole of European accounting reports (Except those published in Cyprus) indicate the elements related to the title and the signature of auditors. The auditor's signature is either in the name of the audit firm, the personal name of the auditor or both, as appropriate in the respective particular jurisdictions.

For the reports on consolidated and separate financial statements, the results emerged from the analysis of differences between the expected scores and the compliance scores show that no elements required in the development of the introductory paragraph, management's responsibility, auditor's responsibility, auditor's opinion and other responsibilities are perfectly respected by the independent auditors (Table 7). This failure of compliance is also recorded for other elements of standard that cover the addressee, the date of report and the auditor's address.

The results of the Chi-square test for one sample reject the hypothesis of equal percentages of compliance with thirty-eight standardised elements. Regarding the comparability between audit reports on separate and consolidated financial statements the statistics (which obtained from the Chi-square test for two samples) confirm the homogeneity hypothesis of the compliance percentages with the revised ISA 700 (Table 8.2). 
Table 7. Gap analysis between the expected scores and the observed compliance score with international standard on auditor's report (Reports related to the separate and consolidated financial statements)

\begin{tabular}{|c|c|c|c|c|c|c|c|c|c|c|c|}
\hline \multirow{2}{*}{$\begin{array}{l}\text { Countries } \\
\text { of } \\
\text { European } \\
\text { Union }\end{array}$} & \multirow{2}{*}{$\begin{array}{l}\text { Audit } \\
\text { reports }\end{array}$} & \multirow{2}{*}{$\begin{array}{l}\text { Total } \\
\text { gap } \\
(\%)\end{array}$} & \multicolumn{9}{|c|}{ Partial gap between the expected scores and the compliance score with international standard on auditor's report } \\
\hline & & & Addressee & $\begin{array}{c}\text { Introductory } \\
\text { paragraph }\end{array}$ & $\begin{array}{c}\text { Management's } \\
\text { responsibility }\end{array}$ & $\begin{array}{c}\text { Auditor's } \\
\text { responsibility }\end{array}$ & $\begin{array}{c}\text { auditor's } \\
\text { opinion }\end{array}$ & $\begin{array}{c}\text { Other } \\
\text { responsibilities }\end{array}$ & $\begin{array}{l}\text { Auditor's } \\
\text { signature }\end{array}$ & $\begin{array}{l}\text { Date } \\
\text { of the } \\
\text { report }\end{array}$ & $\begin{array}{c}\text { Auditor's } \\
\text { address }\end{array}$ \\
\hline Austria & separate & $-1(-3 \%)$ & - & - & - & - & - & - & - & - & $\begin{array}{c}-1 \\
(-100 \%)\end{array}$ \\
\hline Belgium & separate & $\begin{array}{c}-80 \\
(-21 \%)\end{array}$ & $-3(-30 \%)$ & $-44(-63 \%)$ & $-3 \%(-4 \%)$ & $-24(-17 \%)$ & - & - & - & - & $-6(-60 \%)$ \\
\hline Bulgaria & separate & $-3(-2 \%)$ & - & - & - & - & - & $-2(-40 \%)$ & & & $-1(-20 \%)$ \\
\hline Cyprus & separate & $\begin{array}{c}-16 \\
(-21 \%)\end{array}$ & $\begin{array}{c}-2 \\
(-100 \%)\end{array}$ & $-1(-7 \%)$ & $-7(-44 \%)$ & $-3(-11 \%)$ & - & $-1(-50 \%)$ & - & - & $\begin{array}{c}-2 \\
(-100 \%)\end{array}$ \\
\hline $\begin{array}{l}\text { Czech } \\
\text { Republic }\end{array}$ & separate & $-9(-3 \%)$ & $-1(-14 \%)$ & $-2(-4 \%)$ & - & - & - & $-1(-86 \%)$ & - & - & - \\
\hline Denmark & separate & $\begin{array}{c}-12 \\
(-6 \%) \\
\end{array}$ & $-1(-33 \%)$ & $-5(-24 \%)$ & - & - & - & $-3(-100 \%)$ & - & - & $\begin{array}{c}-3 \\
(-100 \%) \\
\end{array}$ \\
\hline Estonia & separate & $-1(-3 \%)$ & - & - & - & - & - & $-1(-100 \%)$ & - & - & - \\
\hline Finland & separate & $-1(-3 \%)$ & - & - & - & - & - & $-1(-100 \%)$ & - & - & - \\
\hline France & separate & $\begin{array}{c}-229 \\
(-50 \%)\end{array}$ & -5 & -48 & -93 & -72 & & & & -2 & -9 \\
\hline Germany & separate & $\begin{array}{c}-51 \\
(-45 \%)\end{array}$ & $\begin{array}{c}-3 \\
(-100 \%)\end{array}$ & $-10(48 \%)$ & $-21(-87,5 \%)$ & $-13(-31 \%)$ & - & $-1(-33 \%)$ & - & - & $\begin{array}{c}-3 \\
(-100 \%)\end{array}$ \\
\hline Greece & separate & $-4(-3 \%)$ & - & $-3(-11 \%)$ & - & - & - & $-1(-25 \%)$ & - & - & - \\
\hline Hungary & separate & $\begin{array}{c}-45 \\
(-38 \%)\end{array}$ & - & $-6(-29 \%)$ & $-15(-62,5 \%)$ & $-17(-40 \%)$ & $\begin{array}{c}-4 \\
(-44 \%)\end{array}$ & $-3(-100 \%)$ & - & - & - \\
\hline Ireland & separate & $\begin{array}{c}-49 \\
(-41 \%)\end{array}$ & $-1(-33 \%)$ & $-6(-29 \%)$ & $-1(-33 \%)$ & $-1(-4 \%)$ & - & - & - & $\begin{array}{c}-1 \\
(-33 \%)\end{array}$ & $\begin{array}{c}-3 \\
(-100 \%)\end{array}$ \\
\hline Italy & separate & $\begin{array}{c}-13 \\
(-34 \%)\end{array}$ & - & $-2(-29 \%)$ & $-7(-87,5 \%)$ & $-3(-21 \%)$ & - & $-1(-100 \%)$ & - & - & - \\
\hline Latvia & separate & $-4(-4 \%)$ & - & - & - & - & - & $-3(-100 \%)$ & - & - & $-1(-33 \%)$ \\
\hline Lithuania & separate & $-4(-3 \%)$ & - & - & - & - & - & $-4(-100 \%)$ & - & - & - \\
\hline Luxembourg & separate & $-9(-5 \%)$ & $-2(-40 \%)$ & $-2(-6 \%)$ & - & - & - & - & - & $\begin{array}{c}-1 \\
(-25 \%)\end{array}$ & $-4(-80 \%)$ \\
\hline Malta & separate & $\begin{array}{c}-37 \\
(14 \%)\end{array}$ & - & $-8(-16 \%)$ & $-14(-25 \%)$ & $-6(-6 \%)$ & $\begin{array}{c}-2 \\
(-10 \%)\end{array}$ & $-4(-57 \%)$ & & $\begin{array}{c}-1 \\
(-14 \%)\end{array}$ & $-2(-28 \%)$ \\
\hline Poland & separate & $\begin{array}{c}-12 \\
(-8 \%)\end{array}$ & - & - & $-6(-19 \%)$ & $-5(-9 \%)$ & - & - & - & - & $-1(-25 \%)$ \\
\hline Portugal & separate & $\begin{array}{c}-16 \\
(-21 \%)\end{array}$ & $-1(-50 \%)$ & $-1(-7 \%)$ & $-7(-44 \%)$ & $-3(-11 \%)$ & $\begin{array}{c}-1 \\
(-17 \%)\end{array}$ & $-2(-100 \%)$ & - & - & $-1(-50 \%)$ \\
\hline
\end{tabular}




\begin{tabular}{|c|c|c|c|c|c|c|c|c|c|c|c|}
\hline Romania & separate & $\begin{array}{c}-14 \\
(-18 \%)\end{array}$ & - & $-2(-14 \%)$ & $-7(-44 \%)$ & $-3(-11 \%)$ & - & $-1(-50 \%)$ & - & - & $-1(-50 \%)$ \\
\hline Slovakia & separate & $\begin{array}{c}-15 \\
(-20 \%)\end{array}$ & - & $-3(-21 \%)$ & $-7(-44 \%)$ & $-3(-11 \%)$ & - & $-2(-100 \%)$ & - & - & - \\
\hline Slovenia & separate & $-5(-4 \%)$ & - & - & - & - & - & $-2(-67 \%)$ & - & - & $\begin{array}{c}-3 \\
(-100 \%)\end{array}$ \\
\hline Spain & separate & $\begin{array}{c}-17 \\
(-45 \%)\end{array}$ & - & $-1(-14)$ & $-7(-88 \%)$ & $-8(-57 \%)$ & - & $-1(-100 \%)$ & - & - & - \\
\hline Sweden & separate & $\begin{array}{c}-135 \\
(-39 \%)\end{array}$ & - & $-36(-57 \%)$ & $-63(-86 \%)$ & $-27(-21 \%)$ & - & - & - & - & $\begin{array}{c}-9 \\
(-100 \%)\end{array}$ \\
\hline $\begin{array}{l}\text { The } \\
\text { Netherlands }\end{array}$ & separate & $-6(-8 \%)$ & $-1(-50 \%)$ & $-2(-14 \%)$ & - & - & - & $-1(-50 \%)$ & - & - & $\begin{array}{c}-2 \\
(-100 \%)\end{array}$ \\
\hline UK & separate & -74 & $-2(-40 \%)$ & $-10(-29 \%)$ & $-35(-88 \%)$ & $-20(-29 \%)$ & - & $-2(-40 \%)$ & - & $\begin{array}{c}-1 \\
(-20 \%)\end{array}$ & $-4(-80 \%)$ \\
\hline Austria & consolidated & $\begin{array}{c}71 \\
(-16 \%) \\
\end{array}$ & $-1(-8 \%)$ & $-12(-14 \%)$ & $-21(-22 \%)$ & $-13(-8 \%)$ & - & $-2(-17 \%)$ & - & - & $\begin{array}{c}-12 \\
(-100 \%) \\
\end{array}$ \\
\hline Belgium & consolidated & $-3(-4 \%)$ & - & - & - & $-1(-4 \%)$ & - & - & - & - & $\begin{array}{c}-2 \\
(-100 \%)\end{array}$ \\
\hline Bulgaria & consolidated & $\begin{array}{c}-11 \\
(-10 \%)\end{array}$ & - & $-5(-24 \%)$ & $-1(-4 \%)$ & $-2(-5 \%)$ & - & $-1(-33 \%)$ & - & - & $-2(-67 \%)$ \\
\hline Cyprus & consolidated & $-7(-3 \%)$ & $-1(-17 \%)$ & - & - & - & - & - & $-2(-33 \%)$ & - & $-4(-67 \%)$ \\
\hline Denmark & consolidated & $\begin{array}{c}-21 \\
(-11 \%)\end{array}$ & - & $-10(-29 \%)$ & - & - & - & $-5(-100 \%)$ & - & $\begin{array}{c}-1 \\
(-20 \%)\end{array}$ & $\begin{array}{c}-5 \\
(-100 \%)\end{array}$ \\
\hline Estonia & consolidated & $-5(-3 \%)$ & - & - & - & - & - & $-5(-100 \%)$ & - & - & - \\
\hline Finland & consolidated & $\begin{array}{c}-75 \\
(-49 \%)\end{array}$ & - & $-8(-29 \%)$ & $-30(-6 \%)$ & $-31(-55 \%)$ & $\begin{array}{c}-2 \\
(-17 \%)\end{array}$ & - & - & - & $\begin{array}{c}-4 \\
(-100 \%)\end{array}$ \\
\hline France & consolidated & $\begin{array}{c}-73 \\
(-48 \%)\end{array}$ & $-1(-25 \%)$ & $-16(-57 \%)$ & $-31(-97 \%)$ & $-22(-39 \%)$ & - & - & - & - & $-3(-75 \%)$ \\
\hline Germany & consolidated & $\begin{array}{c}-118 \\
(-44 \%)\end{array}$ & $-6(-86 \%)$ & $-20(-41 \%)$ & $-49(-87,5 \%)$ & $-33(-34 \%)$ & - & $-4(-57 \%)$ & - & - & $-6(-86 \%)$ \\
\hline Greece & consolidated & - & - & - & - & - & - & - & - & - & - \\
\hline Hungary & consolidated & $\begin{array}{c}-10 \\
(-7 \%)\end{array}$ & - & - & - & - & $\begin{array}{c}-4 \\
(-33 \%)\end{array}$ & $-4(-100 \%)$ & - & - & $-2(-50 \%)$ \\
\hline Ireland & consolidated & $\begin{array}{c}-45 \\
(-39 \%)\end{array}$ & - & $-6(-29 \%)$ & $-21(-87,5 \%)$ & $-15(-36 \%)$ & - & - & - & - & $\begin{array}{c}-3 \\
(-100 \%)\end{array}$ \\
\hline Italy & consolidated & $\begin{array}{c}-77 \\
(-34 \%)\end{array}$ & - & $-12(-29 \%)$ & $-42(-87,5 \%)$ & $-18(-21 \%)$ & - & $-5(-83 \%)$ & - & - & - \\
\hline Latvia & consolidated & $\begin{array}{c}-1 \\
(-0.88 \%)\end{array}$ & - & - & - & - & - & - & - & $\begin{array}{c}-1 \\
(-33 \%)\end{array}$ & - \\
\hline Lithuania & consolidated & - & - & - & - & - & - & - & - & - & - \\
\hline
\end{tabular}




\begin{tabular}{|c|c|c|c|c|c|c|c|c|c|c|c|}
\hline Malta & consolidated & $-2(-3 \%)$ & - & - & - & - & - & $-1(-50 \%)$ & - & - & $-1(-50 \%)$ \\
\hline Poland & consolidated & - & - & - & - & - & - & - & - & - & - \\
\hline Portugal & consolidated & $\begin{array}{c}-26 \\
(-34 \%)\end{array}$ & $\begin{array}{c}-2 \\
(-100 \%)\end{array}$ & $-2(-7 \%)$ & $-10(-62.5 \%)$ & $-8(-29 \%)$ & - & $-2(-100 \%)$ & - & - & $\begin{array}{c}-2 \\
(-100 \%)\end{array}$ \\
\hline Romania & consolidated & $-3(-2 \%)$ & - & - & - & - & - & $-1(-25 \%)$ & - & - & $-2(-50 \%)$ \\
\hline Slovenia & consolidated & $-1(-3 \%)$ & - & - & - & - & - & - & - & - & $\begin{array}{c}-1 \\
(-100 \%)\end{array}$ \\
\hline Spain & consolidated & $\begin{array}{c}-89 \\
(-39 \%)\end{array}$ & - & $-8(-19 \%)$ & $-42(-87.5 \%)$ & $-39(-46 \%)$ & - & - & - & - & - \\
\hline Sweden & consolidated & $\begin{array}{c}-135 \\
(-39 \%)\end{array}$ & - & $-36(-57 \%)$ & $-63(-87.5 \%)$ & $-27(-21 \%)$ & - & - & - & - & $\begin{array}{c}-9 \\
(-100 \%)\end{array}$ \\
\hline $\begin{array}{l}\text { The } \\
\text { Netherlands }\end{array}$ & consolidated & $-2(-5 \%)$ & - & - & - & - & - & - & - & - & $\begin{array}{c}-2 \\
(-100 \%)\end{array}$ \\
\hline UK & consolidated & $\begin{array}{c}-138 \\
(-40 \%)\end{array}$ & $-1(-11 \%)$ & $-26(-41 \%)$ & $-63(-87.5 \%)$ & $-37(-29 \%)$ & - & $-5(-56 \%)$ & - & - & $-6(-67 \%)$ \\
\hline
\end{tabular}

Table 8. Chi-square tests for equality of the percentages

\begin{tabular}{|l|c|c|}
\hline \multicolumn{3}{|c|}{ Table 8.1. Table of the frequencies } \\
\hline Elements of IFAC's report - Revised ISA 700 & $\begin{array}{c}\text { Separate } \\
\text { auditors' } \\
\text { reports }\end{array}$ & $\begin{array}{c}\text { Consolidated } \\
\text { auditors' } \\
\text { reports }\end{array}$ \\
\hline Title & 105 & 116 \\
\hline Addressee & 83 & 94 \\
\hline Introductory paragraph & & \\
\hline Identification of the entity whose financial statements have been audited & 98 & 114 \\
\hline Statement that the financial statements have been audited & 105 & 116 \\
\hline Identification of the title of each of the financial statements & 74 & 98 \\
\hline Reference to the summary of significant accounting policies & 47 & 58 \\
\hline Reference to other explanatory notes & 63 & 86 \\
\hline Specify the date covered by the financial statements & 56 & 65 \\
\hline Specify the period covered by the financial statements & 100 & 114 \\
\hline Management's responsibility for the financial statements & Separate & Consolidated \\
\hline $\begin{array}{l}\text { Statement that management is responsible for the preparation of the } \\
\text { financial statements }\end{array}$ & 94 & 111 \\
\hline $\begin{array}{l}\text { Statement that management is responsible for the fair presentation of the } \\
\text { financial statements }\end{array}$ & 60 & 63 \\
\hline Statement that this responsibility includes designing internal control & 62 & 63 \\
\hline
\end{tabular}




\begin{tabular}{|c|c|c|}
\hline Statement that this responsibility includes implementing internal control & 62 & 63 \\
\hline Statement that this responsibility includes maintaining internal control & 62 & 64 \\
\hline $\begin{array}{l}\text { Statement that this responsibility includes selecting appropriate accounting } \\
\text { policies }\end{array}$ & 62 & 63 \\
\hline $\begin{array}{l}\text { Statement that this responsibility includes applying appropriate accounting } \\
\text { policies }\end{array}$ & 62 & 65 \\
\hline $\begin{array}{l}\text { Statement that this responsibility includes making accounting estimates } \\
\text { that are reasonable in the circumstances }\end{array}$ & 62 & 63 \\
\hline Auditor's responsibility & Separate & Consolidated \\
\hline $\begin{array}{l}\text { Statement that the responsibility of the auditor is to express an opinion on } \\
\text { the financial statements based on the audit }\end{array}$ & 101 & 109 \\
\hline $\begin{array}{l}\text { Statement that the audit was conducted in accordance with International } \\
\text { Standards on Auditing }\end{array}$ & 104 & 116 \\
\hline $\begin{array}{l}\text { Explanation that those standards require that the auditor comply with } \\
\text { ethical requirements to obtain reasonable assurance whether the financial } \\
\text { statements are free from material misstatement }\end{array}$ & 52 & 61 \\
\hline $\begin{array}{l}\text { Explanation that those standards require that the auditor plan the audit to } \\
\text { obtain reasonable assurance whether the financial statements are free from } \\
\text { material misstatement }\end{array}$ & 90 & 102 \\
\hline $\begin{array}{l}\text { Explanation that those standards require that the auditor perform the audit } \\
\text { to obtain reasonable assurance whether the financial statements are free } \\
\text { from material misstatement }\end{array}$ & 102 & 112 \\
\hline $\begin{array}{l}\text { Description an audit by stating that an audit involves performing } \\
\text { procedures to obtain audit evidence about the amounts in the financial } \\
\text { statements }\end{array}$ & 94 & 104 \\
\hline $\begin{array}{l}\text { Description an audit by stating that an audit involves performing } \\
\text { procedures to obtain audit evidence about disclosures in the financial } \\
\text { statements }\end{array}$ & 95 & 112 \\
\hline $\begin{array}{l}\text { Description an audit by stating that the procedures selected depend on the } \\
\text { auditor's judgment, including the assessment of the risks of material } \\
\text { misstatement of the financial statements, whether due to fraud or error }\end{array}$ & 57 & 62 \\
\hline $\begin{array}{l}\text { Description an audit by stating that in making those risk assessments, the } \\
\text { auditor considers internal control relevant to the entity's preparation and } \\
\text { fair presentation of the financial statements in order to design audit } \\
\text { procedures that are appropriate in the circumstances, but not for the } \\
\text { purpose of expressing an opinion on the effectiveness of the entity's } \\
\text { internal control }\end{array}$ & 60 & 69 \\
\hline $\begin{array}{l}\text { Description an audit by stating that an audit also includes evaluating the } \\
\text { appropriateness of the accounting policies used }\end{array}$ & 103 & 116 \\
\hline $\begin{array}{l}\text { Description an audit by stating that an audit also includes evaluating the } \\
\text { reasonableness of accounting estimates made by management }\end{array}$ & 104 & 115 \\
\hline $\begin{array}{l}\text { Description an audit by stating that an audit also includes evaluating the } \\
\text { overall presentation of the financial statements }\end{array}$ & 104 & 115 \\
\hline
\end{tabular}




\section{Macrothink}

International Journal of Accounting and Financial Reporting

ISSN 2162-3082

2012, Vol. 2, No. 2

\begin{tabular}{|c|c|c|}
\hline $\begin{array}{l}\text { Statement that the auditor believes that the audit evidence the auditor has } \\
\text { obtained is sufficient to provide a basis for the auditor's opinion }\end{array}$ & 91 & 95 \\
\hline $\begin{array}{l}\text { Statement that the auditor believes that the audit evidence the auditor has } \\
\text { obtained is appropriate to provide a basis for the auditor's opinion }\end{array}$ & 90 & 90 \\
\hline Auditor's opinion & Separate & Consolidated \\
\hline $\begin{array}{l}\text { The auditor's opinion that the financial statements give a true and fair view } \\
\text { or present fairly, in all material respects }\end{array}$ & 105 & 116 \\
\hline $\begin{array}{l}\text { The auditor's opinion that the financial statements are in accordance with } \\
\text { the applicable financial reporting framework }\end{array}$ & 102 & 113 \\
\hline $\begin{array}{l}\text { The reference to the financial reporting framework in the wording of the } \\
\text { opinion should identify the jurisdiction or country of origin of the financial } \\
\text { reporting framework }\end{array}$ & 101 & 113 \\
\hline Other reporting responsibilities & 63 & 80 \\
\hline Auditor's Signature & 105 & 114 \\
\hline Date of the Auditor's Report & 99 & 114 \\
\hline Auditor's Address & 49 & 49 \\
\hline \multicolumn{3}{|l|}{ Table 8.2. Chi-square tests } \\
\hline \multirow[t]{2}{*}{ Chi-square test for one sample } & $\begin{array}{c}\text { Observed } \\
\text { value } \\
\text { (critical } \\
\text { value) } \\
\end{array}$ & $\begin{array}{c}\text { Observed } \\
\text { value } \\
\text { (critical } \\
\text { value) } \\
\end{array}$ \\
\hline & $\begin{array}{l}226.817 \\
(52.192)\end{array}$ & $\begin{array}{l}273.551 \\
(52.192)\end{array}$ \\
\hline \multirow[t]{2}{*}{ Chi-square test for one samples } & \multicolumn{2}{|c|}{$\begin{array}{l}\text { Observed value } \\
\text { (critical value) }\end{array}$} \\
\hline & \multicolumn{2}{|c|}{$\begin{array}{c}6.966 \\
(52.192)\end{array}$} \\
\hline
\end{tabular}

5.2.2. The comparability of the European auditor's reports on consolidated and separate financial statements

One of the required characteristics for the quality of accounting and auditing information is comparability. This characteristic implies that users would prefer to have auditor's reports that they can easily compare between entities and over time (consistency) for a specific entity. The desire to increase the relevance of auditor's reports by improving their comparability has led to the development of standard auditor's reports (Fédération des Experts Comptables Européens, 2000). The comparability enhances the quality of accounting information and leads to the harmonisation of accounting. The homogeneity (as corollary of the comparability) leads to the improvement of transparency of financial reporting practices.

In order to improve the statistical analysis and to enrich the interpretation of results, we adopt two comparative approaches. 
The first approach is based on the comparison of compliance percentages. It is based on the analysis of conditional and marginal frequency tables. The chi-square test was chosen for the analysis of these tables. These tables are presented in appendix (1) and (2).

The second approach is based on the analysis of scores comparability of compliance with the principles of standard ISA700. The analysis of these scores is assisted by the comparison tests of means and variances.

On the basis of the results obtained from the first approach, it was proved that the European independent auditors do not share the same perceptions of the importance and the informational utility of the new revised ISA700 elements. As can be seen from the statistics displayed in Table (9), the European accounting reports (on separate and consolidated financial statements) do not uniformly apply the requirements which related to addressee, introductory paragraph, management's responsibility for the financial statements, auditor's responsibility, auditor's opinion, other reporting responsibilities and auditor's Address. Regarding the elements related to title, auditor's signature and date of the auditor's report (on separate and consolidated statements) the assumption of homogeneity of European audit practices is justified by the marginal and conditional statistical analysis.

The same conclusion on the heterogeneity of European reports is confirmed by the results of the second approach. The comparative test of the average scores (ANOVA Test) rejects the assumption of harmony among the European auditing reports on separate and consolidated statements (Tables 10). The Levene's test confirms the same assumption and confirms the conclusion of the significant variance inequality of the scores (Tables 11).

Table 9. Chi-square tests of homogeneity of European auditor's reports (Tests for the equality of proportions)

\begin{tabular}{|c|c|c|c|c|c|}
\hline \multirow[t]{2}{*}{ Elements } & \multirow[t]{2}{*}{ Auditor's report } & \multicolumn{2}{|c|}{ Conditional analysis } & \multicolumn{2}{|c|}{ Marginal analysis } \\
\hline & & $\begin{array}{c}\text { Chi-square (critical } \\
\text { value) }\end{array}$ & DF & $\begin{array}{c}\text { Chi-square (critical } \\
\text { value) }\end{array}$ & DF \\
\hline \multirow[t]{3}{*}{ Title } & Separate & - & - & \multirow[t]{3}{*}{-} & \multirow[t]{3}{*}{26} \\
\hline & $\begin{array}{l}\text { Consolidated } \\
\text { statements }\end{array}$ & - & - & & \\
\hline & $\begin{array}{l}\text { Separate and } \\
\text { consolidated }\end{array}$ & - & - & & \\
\hline \multirow[t]{3}{*}{ Addressee } & Separate & $40.956(38.885)$ & 26 & \multirow[t]{3}{*}{$106.604(38.885)$} & \multirow[t]{3}{*}{26} \\
\hline & $\begin{array}{l}\text { Consolidated } \\
\text { statements }\end{array}$ & $88.372(38.885)$ & 26 & & \\
\hline & $\begin{array}{l}\text { Separate and } \\
\text { consolidated }\end{array}$ & $129.328(69.832)$ & 52 & & \\
\hline \multirow{3}{*}{$\begin{array}{l}\text { Other reporting } \\
\text { responsibilities }\end{array}$} & Separate & $69.355(38.885)$ & 26 & \multirow[t]{3}{*}{$112.468(38.885)$} & \multirow[t]{3}{*}{26} \\
\hline & $\begin{array}{l}\text { Consolidated } \\
\text { statements }\end{array}$ & $76.972(38.885)$ & 26 & & \\
\hline & $\begin{array}{l}\text { Separate and } \\
\text { consolidated }\end{array}$ & $146.327(69.832)$ & & & \\
\hline Auditor's & Separate & - & - & $53.736(38.885)$ & 26 \\
\hline
\end{tabular}




\begin{tabular}{|c|c|c|c|c|c|}
\hline \multirow[t]{2}{*}{ Signature } & $\begin{array}{l}\text { Consolidated } \\
\text { statements }\end{array}$ & $37.310(38.885)$ & 26 & & \\
\hline & $\begin{array}{l}\text { Separate and } \\
\text { consolidated }\end{array}$ & - & - & & \\
\hline \multirow{3}{*}{$\begin{array}{l}\text { Date of the } \\
\text { Auditor's Report }\end{array}$} & Separate & $16.086(38.885)$ & 26 & \multirow[t]{3}{*}{$22.011(38.885)$} & \multirow[t]{3}{*}{26} \\
\hline & $\begin{array}{l}\text { Consolidated } \\
\text { statements }\end{array}$ & $29.441(38.885)$ & 26 & & \\
\hline & $\begin{array}{l}\text { Separate and } \\
\text { consolidated }\end{array}$ & $45.527(69.832)$ & 52 & & \\
\hline \multirow[t]{3}{*}{ Auditor's Address } & Separate & $61.224(38.885)$ & 26 & \multirow[t]{3}{*}{$127.094(38.885)$} & \multirow[t]{3}{*}{26} \\
\hline & $\begin{array}{l}\text { Consolidated } \\
\text { statements }\end{array}$ & $82.771(38.885)$ & 26 & & \\
\hline & $\begin{array}{l}\text { Separate and } \\
\text { consolidated }\end{array}$ & $143.995(69.832)$ & 52 & & \\
\hline \multirow{3}{*}{$\begin{array}{l}\text { Introductory } \\
\text { paragraph }\end{array}$} & Separate & $215.741(38.885)$ & 26 & \multirow[t]{3}{*}{376.789 (38.885) } & \multirow[t]{3}{*}{26} \\
\hline & $\begin{array}{l}\text { Consolidated } \\
\text { statements }\end{array}$ & $199.326(38.885)$ & 26 & & \\
\hline & $\begin{array}{l}\text { Separate and } \\
\text { consolidated }\end{array}$ & 415.067 (69.832) & & & \\
\hline \multirow{3}{*}{$\begin{array}{l}\text { Management's } \\
\text { responsibility for } \\
\text { the financial } \\
\text { statements }\end{array}$} & Separate & $579.392(38.885)$ & 26 & \multirow[t]{3}{*}{$1186.051(38.885)$} & \multirow[t]{3}{*}{26} \\
\hline & $\begin{array}{l}\text { Consolidated } \\
\text { statements }\end{array}$ & $682.733(38.885)$ & 26 & & \\
\hline & $\begin{array}{l}\text { Separate and } \\
\text { consolidated }\end{array}$ & $1262.125(69.832)$ & 52 & & \\
\hline \multirow{3}{*}{$\begin{array}{l}\text { Auditor's } \\
\text { responsibility }\end{array}$} & Separate & $287.176(38.885)$ & 26 & \multirow[t]{3}{*}{$579.775(38.885)$} & \multirow[t]{3}{*}{26} \\
\hline & $\begin{array}{l}\text { Consolidated } \\
\text { statements }\end{array}$ & $366.033(38.885)$ & 26 & & \\
\hline & $\begin{array}{l}\text { Separated and } \\
\text { consolidated }\end{array}$ & $653.209(69.832)$ & 52 & & \\
\hline \multirow[t]{3}{*}{ Auditor's opinion } & Separate & $91.096(38.885)$ & 26 & \multirow[t]{3}{*}{$171.191(38.885)$} & \multirow[t]{3}{*}{26} \\
\hline & $\begin{array}{l}\text { Consolidated } \\
\text { statements }\end{array}$ & $92.257(38.885)$ & 26 & & \\
\hline & $\begin{array}{l}\text { Separate and } \\
\text { consolidated }\end{array}$ & $183.353(69.832)$ & 52 & & \\
\hline \multirow[t]{3}{*}{ All elements } & Separate & 725.973 (38.885) & 26 & \multirow[t]{3}{*}{$1479.499(38.885)$} & \multirow[t]{3}{*}{26} \\
\hline & $\begin{array}{l}\text { Consolidated } \\
\text { statements }\end{array}$ & 891.659 (38.885) & 26 & & \\
\hline & $\begin{array}{l}\text { Separate and } \\
\text { consolidated }\end{array}$ & $1617.632(69.832)$ & 52 & & \\
\hline
\end{tabular}


Table 10. ANOVA test for European auditors'reports on separate and consolidated financial statements

\begin{tabular}{|c|c|c|c|c|c|c|c|c|c|}
\hline \multirow[t]{2}{*}{ Elements } & \multirow[t]{2}{*}{$\begin{array}{l}\text { Auditor's } \\
\text { report }\end{array}$} & \multicolumn{2}{|c|}{ Sum of Squares } & \multicolumn{2}{|c|}{$\begin{array}{l}\text { Degree of } \\
\text { Freedom }\end{array}$} & \multicolumn{2}{|c|}{ Mean Square } & \multirow[t]{2}{*}{$\mathbf{F}$} & \multirow{2}{*}{$\begin{array}{c}\text { F } \\
\text { (critical } \\
\text { value) }\end{array}$} \\
\hline & & Between & Within & Between & Within & Between & Within & & \\
\hline \multirow[t]{3}{*}{ Title } & $\begin{array}{l}\text { Separate } \\
\text { statements }\end{array}$ & 0 & 0 & 26 & 78 & 0 & 0 & - & 1.638 \\
\hline & $\begin{array}{l}\text { Consolidated } \\
\text { statements }\end{array}$ & 0 & 0 & 26 & 89 & 0 & 0 & - & 1.620 \\
\hline & $\begin{array}{l}\text { Separate and } \\
\text { consolidated }\end{array}$ & 0 & 0 & 26 & 194 & 0 & 0 & - & 1.552 \\
\hline \multirow[t]{3}{*}{ Addressee } & $\begin{array}{l}\text { Separate } \\
\text { statements }\end{array}$ & 6.783 & 10.607 & 26 & 78 & 0.260 & 0.135 & 1.918 & 1.638 \\
\hline & $\begin{array}{l}\text { Consolidated } \\
\text { statements }\end{array}$ & 13.581 & 4.246 & 26 & 89 & 0.522 & 0.0477 & 10.949 & 1.620 \\
\hline & $\begin{array}{l}\text { Separate and } \\
\text { consolidated }\end{array}$ & 16.998 & 18.241 & 26 & 194 & 0.653 & 0.094 & 6.953 & 1.552 \\
\hline \multirow{3}{*}{$\begin{array}{l}\text { Other } \\
\text { reporting } \\
\text { responsibilities }\end{array}$} & $\begin{array}{l}\text { Separate } \\
\text { statements }\end{array}$ & 16.645 & 8.554 & 26 & 78 & 0.640 & 0.109 & 5.837 & 1.638 \\
\hline & $\begin{array}{l}\text { Consolidated } \\
\text { statements }\end{array}$ & 16.474 & 8.353 & 26 & 89 & 0.633 & 0.093 & 6.751 & 1.620 \\
\hline & $\begin{array}{l}\text { Separate and } \\
\text { consolidated }\end{array}$ & 25.684 & 24.785 & 26 & 194 & 0.987 & 0.127 & 7.732 & 1.552 \\
\hline \multirow[t]{3}{*}{$\begin{array}{l}\text { Auditor's } \\
\text { Signature }\end{array}$} & $\begin{array}{l}\text { Separate } \\
\text { statements }\end{array}$ & 0 & 0 & 26 & 78 & 0 & 0 & - & 1.638 \\
\hline & $\begin{array}{l}\text { Consolidated } \\
\text { statements }\end{array}$ & 0.632 & 1.333 & 26 & 89 & 0.024 & 0.014 & 1.6230 & 1.620 \\
\hline & $\begin{array}{l}\text { Separate and } \\
\text { consolidated }\end{array}$ & 0.481 & 1.5 & 26 & 194 & 0.018 & 0.007 & 2.397 & 1.552 \\
\hline \multirow{3}{*}{$\begin{array}{l}\text { Date of the } \\
\text { Auditor's } \\
\text { Report }\end{array}$} & $\begin{array}{l}\text { Separate } \\
\text { statements }\end{array}$ & 0.866 & 4.790 & 26 & 78 & 0.033 & 0.061 & 0.542 & 1.638 \\
\hline & $\begin{array}{l}\text { Consolidated } \\
\text { statements }\end{array}$ & 0.498 & 1.466 & 26 & 89 & 0.019 & 0.016 & 1.164 & 1.620 \\
\hline & $\begin{array}{l}\text { Separate and } \\
\text { consolidated }\end{array}$ & 0.767 & 6.942 & 26 & 194 & 0.029 & 0.035 & 0.825 & 1.552 \\
\hline \multirow[t]{3}{*}{$\begin{array}{l}\text { Auditor's } \\
\text { Address }\end{array}$} & $\begin{array}{l}\text { Separate } \\
\text { statements }\end{array}$ & 15.238 & 10.895 & 26 & 78 & 0.586 & 0.139 & 4.195 & 1.638 \\
\hline & $\begin{array}{l}\text { Consolidated } \\
\text { statements }\end{array}$ & 20.194 & 8.107 & 26 & 89 & 0.776 & 0.091 & 8.526 & 1.620 \\
\hline & $\begin{array}{l}\text { Separate and } \\
\text { consolidated }\end{array}$ & 31.366 & 23.176 & 26 & 194 & 1.206 & 0.119 & 10.098 & 1.552 \\
\hline
\end{tabular}




\begin{tabular}{|c|c|c|c|c|c|c|c|c|c|}
\hline \multirow[t]{3}{*}{$\begin{array}{l}\text { Introductory } \\
\text { paragraph }\end{array}$} & $\begin{array}{l}\text { Separate } \\
\text { statements }\end{array}$ & 291.445 & 61.469 & 26 & 78 & 11.209 & 0.788 & 14.223 & 1.638 \\
\hline & $\begin{array}{l}\text { Consolidated } \\
\text { statements }\end{array}$ & 221.797 & 71.746 & 26 & 89 & 8.530 & 0.806 & 10.582 & 1.620 \\
\hline & $\begin{array}{l}\text { Separate and } \\
\text { consolidated }\end{array}$ & 464.509 & 192.648 & 26 & 194 & 17.865 & 0.993 & 17.991 & 1.552 \\
\hline \multirow[t]{3}{*}{$\begin{array}{l}\text { Management's } \\
\text { responsibility }\end{array}$} & $\begin{array}{l}\text { Separate } \\
\text { statements }\end{array}$ & 1084.973 & 238.016 & 26 & 78 & 41.729 & 3.051 & 13.675 & 1.638 \\
\hline & $\begin{array}{l}\text { Consolidated } \\
\text { statements }\end{array}$ & 1312.945 & 112.666 & 26 & 89 & 50.497 & 1.265 & 39.890 & 1.620 \\
\hline & $\begin{array}{l}\text { Separate and } \\
\text { consolidated }\end{array}$ & 2254.296 & 497.096 & 26 & 194 & 86.703 & 2.562 & 33.837 & 1.552 \\
\hline \multirow[t]{3}{*}{$\begin{array}{l}\text { Auditor's } \\
\text { responsibility }\end{array}$} & $\begin{array}{l}\text { Separate } \\
\text { statements }\end{array}$ & 517.383 & 210.007 & 26 & 78 & 19.899 & 2.692 & 7.390 & 1.638 \\
\hline & $\begin{array}{l}\text { Consolidated } \\
\text { statements }\end{array}$ & 658.659 & 107.650 & 26 & 89 & 25.333 & 1.209 & 20.944 & 1.620 \\
\hline & $\begin{array}{l}\text { Separate and } \\
\text { consolidated }\end{array}$ & 1043.876 & 449.825 & 26 & 194 & 40.149 & 2.318 & 17.315 & 1.552 \\
\hline \multirow[t]{3}{*}{$\begin{array}{l}\text { Auditor's } \\
\text { opinion }\end{array}$} & $\begin{array}{l}\text { Separate } \\
\text { statements }\end{array}$ & 5.938 & 6.595 & 26 & 78 & 0.228 & 0.084 & 2.701 & 1.638 \\
\hline & $\begin{array}{l}\text { Consolidated } \\
\text { statements }\end{array}$ & 4.689 & 7 & 26 & 89 & 0.180 & 0.078 & 2.293 & 1.620 \\
\hline & $\begin{array}{l}\text { Separate and } \\
\text { consolidated }\end{array}$ & 9.872 & 14.362 & 26 & 194 & 0.379 & 0.074 & 5.128 & 1.552 \\
\hline \multirow[t]{3}{*}{ All elements } & $\begin{array}{l}\text { Separate } \\
\text { statements }\end{array}$ & 4672.316 & 1431.073 & 26 & 78 & 179.704 & 18.347 & 9.794 & 1.638 \\
\hline & $\begin{array}{l}\text { Consolidated } \\
\text { statements }\end{array}$ & 5573.385 & 762.157 & 26 & 89 & 214.360 & 8.563 & 25.031 & 1.620 \\
\hline & $\begin{array}{l}\text { Separate and } \\
\text { consolidated }\end{array}$ & 9379.024 & 3065.609 & 26 & 194 & 360.731 & 15.802 & 22.828 & 1.552 \\
\hline
\end{tabular}


Table 11. Levene's test for equality of variance (European auditors' reports on separate/consolidated financial statements)

\begin{tabular}{|c|c|c|c|c|c|c|}
\hline Elements & Auditor's report & $\begin{array}{l}\text { F (observed } \\
\text { value) }\end{array}$ & $\begin{array}{c}\text { F (critical } \\
\text { value) }\end{array}$ & DF 1 & DF 2 & p-value \\
\hline \multirow[t]{3}{*}{ Title } & Separate & - & 1.799 & 26 & 78 & - \\
\hline & Conolidated statements & - & 1.774 & 26 & 89 & - \\
\hline & $\begin{array}{l}\text { Separate and } \\
\text { conolidated }\end{array}$ & - & 1.687 & 26 & 194 & - \\
\hline \multirow[t]{3}{*}{ Addressee } & Separate & 14.263 & 1.799 & 26 & 78 & $\begin{array}{c}< \\
0.0001\end{array}$ \\
\hline & Consolidated statements & 2.296 & 1.776 & 26 & 89 & 0.002 \\
\hline & $\begin{array}{l}\text { Separate and } \\
\text { consolidated }\end{array}$ & 10.961 & 1.687 & 26 & 194 & $\begin{array}{c}< \\
0.0001\end{array}$ \\
\hline \multirow[t]{3}{*}{$\begin{array}{l}\text { Other reporting } \\
\text { responsibilities }\end{array}$} & Separate & 16.139 & 1.799 & 26 & 78 & $\begin{array}{c}< \\
0.0001\end{array}$ \\
\hline & Consolidated statements & 10.762 & 1.776 & 26 & 89 & $\begin{array}{c}< \\
0.0001\end{array}$ \\
\hline & $\begin{array}{l}\text { Separate and } \\
\text { consolidated }\end{array}$ & 17.687 & 1.687 & 26 & 194 & $\begin{array}{c}< \\
0.0001\end{array}$ \\
\hline \multirow[t]{3}{*}{ Auditor's Signature } & Separate & - & 1.799 & 26 & 78 & - \\
\hline & Consolidated statements & 25.968 & 1.776 & 26 & 89 & $\begin{array}{c}< \\
0.0001\end{array}$ \\
\hline & $\begin{array}{l}\text { Separate and } \\
\text { consolidated }\end{array}$ & 21.574 & 1.687 & 26 & 194 & $\begin{array}{c}< \\
0.0001\end{array}$ \\
\hline \multirow[t]{3}{*}{$\begin{array}{l}\text { Date of the Auditor's } \\
\text { Report }\end{array}$} & Separate & 3.427 & 1.799 & 26 & 78 & $\begin{array}{c}< \\
0.0001\end{array}$ \\
\hline & Consolidated statements & 9.742 & 1.776 & 26 & 89 & $\begin{array}{c}< \\
0.0001\end{array}$ \\
\hline & $\begin{array}{l}\text { Separate and } \\
\text { consolidated }\end{array}$ & 4.434 & 1.687 & 26 & 194 & $\begin{array}{c}< \\
0.0001\end{array}$ \\
\hline \multirow[t]{3}{*}{ Auditor's Address } & Separate & 6.343 & 1.799 & 26 & 78 & $\begin{array}{c}< \\
0.0001\end{array}$ \\
\hline & Consolidated statements & 15.275 & 1.776 & 26 & 89 & $\begin{array}{c}< \\
0.0001\end{array}$ \\
\hline & $\begin{array}{l}\text { Separate and } \\
\text { consolidated }\end{array}$ & 12.428 & 1.687 & 26 & 194 & $\begin{array}{c}< \\
0.0001\end{array}$ \\
\hline \multirow[t]{2}{*}{$\begin{array}{l}\text { Introductory } \\
\text { paragraph }\end{array}$} & Separate & 6.752 & 1.799 & 26 & 78 & $\begin{array}{c}< \\
0.0001\end{array}$ \\
\hline & Consolidated statements & 6.726 & 1.776 & 26 & 89 & $\begin{array}{c}< \\
0.0001\end{array}$ \\
\hline
\end{tabular}




\begin{tabular}{|c|c|c|c|c|c|c|}
\hline & $\begin{array}{l}\text { Separate and } \\
\text { consolidated }\end{array}$ & 6.977 & 1.687 & 26 & 194 & $\begin{array}{c}< \\
0.0001\end{array}$ \\
\hline \multirow{3}{*}{$\begin{array}{l}\text { Management's } \\
\text { responsibility for the } \\
\text { financial statements }\end{array}$} & Separate & 18.568 & 1.799 & 26 & 78 & $\begin{array}{c}< \\
0.0001\end{array}$ \\
\hline & Consolidated statements & 9.038 & 1.776 & 26 & 89 & $\begin{array}{c}< \\
0.0001\end{array}$ \\
\hline & $\begin{array}{l}\text { Separate and } \\
\text { consolidated }\end{array}$ & 10.607 & 1.687 & 26 & 194 & $\begin{array}{c}< \\
0.0001\end{array}$ \\
\hline \multirow[t]{3}{*}{$\begin{array}{l}\text { Auditor's } \\
\text { responsibility }\end{array}$} & Separate & 12.001 & 1.799 & 26 & 78 & $\begin{array}{c}< \\
0.0001\end{array}$ \\
\hline & Consolidated statements & 9.246 & 1.776 & 26 & 89 & $\begin{array}{c}< \\
0.0001\end{array}$ \\
\hline & $\begin{array}{l}\text { Separate and } \\
\text { consolidated }\end{array}$ & 6.444 & 1.687 & 26 & 194 & $\begin{array}{c}< \\
0.0001\end{array}$ \\
\hline \multirow[t]{3}{*}{ Auditor's opinion } & Separate & 5.969 & 1.799 & 26 & 78 & $\begin{array}{c}< \\
0.0001\end{array}$ \\
\hline & Consolidated statements & 26.598 & 1.776 & 26 & 89 & $\begin{array}{c}< \\
0.0001\end{array}$ \\
\hline & $\begin{array}{l}\text { Separate and } \\
\text { consolidated }\end{array}$ & 19.934 & 1.687 & 26 & 194 & $\begin{array}{c}< \\
0.0001\end{array}$ \\
\hline \multirow[t]{3}{*}{ All elements } & Separate & 6.998 & 1.799 & 26 & 78 & $\begin{array}{c}< \\
0.0001\end{array}$ \\
\hline & Consolidated statements & 6.747 & 1.776 & 26 & 89 & $\begin{array}{c}< \\
0.0001\end{array}$ \\
\hline & $\begin{array}{l}\text { Separate and } \\
\text { consolidated }\end{array}$ & 6.846 & 1.687 & 26 & 194 & $\begin{array}{c}< \\
0.0001\end{array}$ \\
\hline
\end{tabular}

\section{Implications of empirical results}

On the basis of the results obtained from the statistical tests, this study testifies an European accounting reality. It was confirmed that the IFAC's rules and the European auditors do not share the same perceptions of the usefulness of the new elements related to the revised ISA700. The whole set of European accounting reports do not uniformly apply the requirements of the international standard on auditor's report.

From a professional point of view, the lack of compliance with the standards that contain principles of the issuance of the audit report damage the quality of the audit process and make the achievement of the auditor's overriding goal difficult. Non conformity to the audit guidelines disturbs the auditor's findings and, largely, limits the competitiveness of accounting firms in the auditing market.

The heterogeneity of European audit practices disrupts the comparison of financial information and hinders the informational needs of Stakeholders. The lack of a common language between the independent auditors cannot reduce the expectation gap that distorts the 
interpretation of accounting information.

According to Kohl and Woo (1998), the definition of the expectation gap varies among researchers. Liggio (1974) was the first to apply the term (expectation gap) to auditing. He defined the expectation gap as the difference between the levels of expected performance as envisioned by the independent accountant and by the user of financial statements.

Monroe and Woodliff (1993) defined the audit expectation gap as the difference in beliefs between auditors and the public about the duties and responsibilities assumed by auditors and the messages conveyed by audit reports. Jennings et al. (1993), in their study on the use of audit decision aids to improve auditor adherence to a "standard", are of the opinion that the audit expectation gap is the difference between what the public expects from the auditing profession and what the profession actually provides. This definition is also advocated by Lowe (in his research on the expectation gap in the legal system, 1994) and King (in his study that attempted to determine the degree of harmonisation in the form and content of the auditor's report in the European Union, 1999).

In discussing the role of IFAC standards in the harmonisation of audit reports within the European Union, the research of King (1999) offers the following opinion : "The expectation gap has been the subject of much debate in the European Union (EU).... The issue of expectation gap takes on added complexities when one considers that the Member States in the EU do not share a common language, a common economic, social and political system, nor a common set of generally accepted accounting or auditing standards. The issue of expectation gap becomes even more important when one recognizes the ever increasing cross-border trading, the growing interrelationships among the international capital markets and the greater tendency for EU companies to seek capital and for investors to seek investment opportunities in the international capital markets. Harmonisation in the wording and coverage of the audit report in the EU could help to reduce the expectation gap."

Inconsistencies with all auditing directives hold the auditors responsible for negligence and incompetence to perform auditing work. This responsibility can expose certified public accountants to several penalties for adoption of improper or unethical professional behaviour. These penalties significantly damage the auditor's reputation and accounting firm's credibility.

In many European countries, the inflicted sanctions for Certified Public Accountants that do not conform, exactly, to International Standards on Auditing cover several punishments which cover: warning, written blame, the suspension from performing audits for about one to five years and the removal from the table of the national Institutes of auditors.

The harmonisation of audit information opens up a wide debate in the European Union. The continuity of this debate is linked to the role of the independent auditor in the regulation of corporate governance.

Several initiatives have been undertaken for the European harmonisation of audit reports. The objective of harmonisation is maintained for several reasons such as:

- Improved financial reporting;

- Reducing the Expectation Gap;

- The uniformity of auditing practices;

- The needs of multinationals, major accounting firms and investors. 


\section{Mll Macrothink}

International Journal of Accounting and Financial Reporting

ISSN 2162-3082

2012, Vol. 2, No. 2

Comparability of European audit reports enhances the informational role of financial statements. The realisation of this qualitative characteristic is desired by many Stakeholders. In this paper, we analysed the wording of audit reports that are published in the European Union. Our analyses are based on:

- The extent of compliance reports with International Standards on Auditing;

- The measure of homogeneity quipubliés reports by members of the European Union.

The results show that European harmonisation of audit reports is not fully realised. Variables that may explain the phenomenon of heterogeneity of auditing practices are numerous. These variables consider several factors that are related to cultural and economic specificities.

The contributions of this paper focus on several contributions:

- The analysis of the Revised ISA 700 has not been allocated a detailed attention. The current accounting research was limited to the old version of the international standard on auditing report (Old ISA 700 or IAG 13). Consequently, our article is an important element for the continuity of the empirical investigations on auditing harmonisation.

- The relevance analysis of the revised ISA 700 was not examined in the frame of the corporate governance. Consequently, our article showed that the international audit report must be concretised by the reduction of informational asymmetry between users of accounting data. The same report must be concretised by the minimisation of the costs of information research and the development of the standards.

- The literature review shows that prior researches are interested only in audit reports on the separate financial statements. Our paper analyses for the first time a sample that includes consolidated reports.

- For this article, the empirical study was based on multivariate tests that improve data analysis. More specifically, the interpretation of the results was assisted by conditional statistics that refine the hypothesis testing harmonisation.

\section{References}

- Archer, S., Mcleay, S. and Dufour, J. (1989), “ Audit Report on Financial Statements of European Multinational Companies: A Comparative Study", The Institute of Chartered Accountants in England and Wales, London, England.

- Botez, D. and Pravat, C. (2009), “ Study concerning the differences between the fourth directive and accounting standards from romania ", Annals of Faculty of Economics 3, 791-795.

- Brandao, E. (1997), "Harmonisation comptable en Europe: aperçu 1", Finéco 7, 41-66.

- Colasse, B. (2001), “Comptabilité Générale”, Economica, 7éme édition.

- European Commission. (1996) ), "Green Paper: The role, the position and the liability of the statutory auditor within the european union".

- Fédération Européenne des Experts Comptables (2000), "The auditor's report in Europe", FEE (Survey), 1-119.

- Gangolly, S., Hussein, M.E., Seow, G.S. and Tarn, K. (2002), “ Harmonisation of the auditor's report", The International Journal of Accounting 37, 327-346. 
- Garcia-Benau M.A. and Zorio A. (2004), “Audit Reports on Financial Statements Prepared According to IASB Standards : Empirical Evidence from the European Union", International Journal of Auditing 8, 237-252.

- Jennings, M., Reckers, M.J. and Kneer, D.C. (1993), "The significance of audit decision aids and precase jurists' attitudes on perceptions of audit firm culpability and liability", Contemporary Accounting Research 9, 489-507.

- Koh, H.C. and Woo, E.S. (1998), “The expectation gap in auditing”, Managerial Auditing Journal 13, 147-154.

- King, C.R. (1999), "The measurement of harmonization in the form and content of auditor's report in the European Union", Journal of International Accounting, Auditing and Taxation 8, 23-42.

- Liggio, C.D. (1974), “The expectation gap: the accountant's Waterloo”, Journal of Contemporary Business 3, 27-44.

- Lowe, D.J. (1994), “The expectation gap in the legal system: perception differences between auditors and judges", Journal of Applied Business Research 10, 39-44.

- Monroe, G.S. and Woodliff, D.R. (1993), "The effect of education on the audit expectation gap", Accounting and Finance 33, 61-78.

- Nobes, C. and Parker, R. (2000), "Comparative International Accounting”, Sixth edition, Pearson Education, London.

- Pedhazur, E.J. and Schmelkin, L. (1991), "Measurement, Design, and Analysis: An Integrated Approach", LEA, Hillsdale, NJ.

- Schockaert, D. and and Houyoux, N. (2007), "International Standards on Auditing within the European Union", Forum financier / Revue bancaire et financière 8.

- Wallage, P. (1993), "International audit: a study of audit approach in the Netherlands", European Accounting Review 3, 553-578. 


\section{Appendix 1. Elements of Auditor's Report in compliance with international standard on auditor's report}

\begin{tabular}{|c|c|}
\hline Elements of IFAC's report - Revised ISA 700 (RISA 700) & References \\
\hline Title & ISA 700-18 \\
\hline Addressee & ISA 700-19 \\
\hline \multicolumn{2}{|l|}{ Introductory paragraph } \\
\hline $\begin{array}{l}\text { The introductory paragraph in the auditor's report should identify the entity whose } \\
\text { financial statements have been audited }\end{array}$ & ISA 700-22 \\
\hline $\begin{array}{l}\text { The introductory paragraph in the auditor's report should state that the financial statements } \\
\text { have been audited }\end{array}$ & ISA $700-22$ \\
\hline $\begin{array}{l}\text { The introductory paragraph in the auditor's report should identify the title of each of the } \\
\text { financial statements that comprise the complete set of financial statements }\end{array}$ & ISA 700-22-a \\
\hline $\begin{array}{l}\text { The introductory paragraph in the auditor's report should refer to the summary of } \\
\text { significant accounting policies }\end{array}$ & ISA $700-22-b$ \\
\hline The introductory paragraph in the auditor's report should refer to other explanatory notes & ISA 700-22-b \\
\hline $\begin{array}{l}\text { The introductory paragraph in the auditor's report should specify the date covered by the } \\
\text { financial statements }\end{array}$ & ISA $700-22-c$ \\
\hline $\begin{array}{l}\text { The introductory paragraph in the auditor's report should Specify the period covered by } \\
\text { the financial statements }\end{array}$ & ISA 700-22-c \\
\hline \multicolumn{2}{|l|}{ Management's responsibility for the financial statements } \\
\hline $\begin{array}{l}\text { The auditor's report should state that management is responsible for the preparation of the } \\
\text { financial statements in accordance with the applicable financial reporting framework }\end{array}$ & ISA $700-700-28$ \\
\hline $\begin{array}{l}\text { The auditor's report should state that management is responsible for the fair presentation } \\
\text { of the financial statements in accordance with the applicable financial reporting } \\
\text { framework }\end{array}$ & ISA 700-700-28 \\
\hline $\begin{array}{l}\text { The auditor's report should state that this responsibility includes designing internal control } \\
\text { relevant to the preparation and fair presentation of financial statements that are free from } \\
\text { material misstatement, whether due to fraud or error }\end{array}$ & ISA 700-28-a \\
\hline $\begin{array}{l}\text { The auditor's report should state that this responsibility includes implementing internal } \\
\text { control relevant to the preparation and fair presentation of financial statements that are free } \\
\text { from material misstatement, whether due to fraud or error }\end{array}$ & ISA $700-28-a$ \\
\hline $\begin{array}{l}\text { The auditor's report should state that this responsibility includes maintaining internal } \\
\text { control relevant to the preparation and fair presentation of financial statements that are free } \\
\text { from material misstatement, whether due to fraud or error }\end{array}$ & ISA 700-28-a \\
\hline $\begin{array}{l}\text { The auditor's report should state that this responsibility includes selecting appropriate } \\
\text { accounting policies }\end{array}$ & ISA 700-28-b \\
\hline $\begin{array}{l}\text { The auditor's report should state that this responsibility includes applying appropriate } \\
\text { accounting policies }\end{array}$ & ISA $700-28-b$ \\
\hline $\begin{array}{l}\text { The auditor's report should state that this responsibility includes making accounting } \\
\text { estimates that are reasonable in the circumstances }\end{array}$ & ISA 700-28-c \\
\hline
\end{tabular}




\begin{tabular}{|c|c|}
\hline Auditor's responsibility & \\
\hline $\begin{array}{l}\text { The auditor's report should state that the responsibility of the auditor is to express an } \\
\text { opinion on the financial statements based on the audit }\end{array}$ & ISA $700-32$ \\
\hline $\begin{array}{l}\text { The auditor's report should state that the audit was conducted in accordance with } \\
\text { International Standards on Auditing }\end{array}$ & ISA 700-34 \\
\hline $\begin{array}{l}\text { The auditor's report should also explain that those standards require that the auditor } \\
\text { comply with ethical requirements to obtain reasonable assurance whether the financial } \\
\text { statements are free from material misstatement }\end{array}$ & ISA 700-34 \\
\hline $\begin{array}{l}\text { The auditor's report should also explain that those standards require that the auditor plan } \\
\text { the audit to obtain reasonable assurance whether the financial statements are free from } \\
\text { material misstatement }\end{array}$ & ISA 700-34 \\
\hline $\begin{array}{l}\text { The auditor's report should also explain that those standards require that the auditor } \\
\text { perform the audit to obtain reasonable assurance whether the financial statements are free } \\
\text { from material misstatement }\end{array}$ & ISA 700-34 \\
\hline $\begin{array}{l}\text { The auditor's report should describe an audit by stating that an audit involves performing } \\
\text { procedures to obtain audit evidence about the amounts in the financial statements }\end{array}$ & ISA 700-37 \\
\hline $\begin{array}{l}\text { The auditor's report should describe an audit by stating that an audit involves performing } \\
\text { procedures to obtain audit evidence about disclosures in the financial statements }\end{array}$ & ISA 700-37-a \\
\hline $\begin{array}{l}\text { The auditor's report should describe an audit by stating that the procedures selected depend } \\
\text { on the auditor's judgment, including the assessment of the risks of material misstatement } \\
\text { of the financial statements, whether due to fraud or error }\end{array}$ & ISA 700-37-b \\
\hline $\begin{array}{l}\text { The auditor's report should describe an audit by stating that in making those risk } \\
\text { assessments, the auditor considers internal control relevant to the entity's preparation and } \\
\text { fair presentation of the financial statements in order to design audit procedures that are } \\
\text { appropriate in the circumstances, but not for the purpose of expressing an opinion on the } \\
\text { effectiveness of the entity's internal control }\end{array}$ & ISA 700-37-b \\
\hline $\begin{array}{l}\text { The auditor's report should describe an audit by stating that an audit also includes } \\
\text { evaluating the appropriateness of the accounting policies used }\end{array}$ & ISA 700-37-c \\
\hline $\begin{array}{l}\text { The auditor's report should describe an audit by stating that an audit also includes } \\
\text { evaluating the reasonableness of accounting estimates made by management }\end{array}$ & ISA 700-37-c \\
\hline $\begin{array}{l}\text { The auditor's report should describe an audit by stating that an audit also includes } \\
\text { evaluating the overall presentation of the financial statements }\end{array}$ & ISA 700-37-c \\
\hline $\begin{array}{l}\text { The auditor's report should state that the auditor believes that the audit evidence the auditor } \\
\text { has obtained is sufficient to provide a basis for the auditor's opinion }\end{array}$ & ISA 700-38 \\
\hline $\begin{array}{l}\text { The auditor's report should state that the auditor believes that the audit evidence the auditor } \\
\text { has obtained is appropriate to provide a basis for the auditor's opinion }\end{array}$ & ISA 700-38 \\
\hline Auditor's opinion & \\
\hline $\begin{array}{l}\text { When expressing an unqualified opinion, the opinion paragraph of the auditor's report } \\
\text { should state the auditor's opinion that the financial statements give a true and fair view or } \\
\text { present fairly, in all material respects }\end{array}$ & ISA $700-40$ \\
\hline $\begin{array}{l}\text { When expressing an unqualified opinion, the opinion paragraph of the auditor's report } \\
\text { should state the auditor's opinion that the financial statements are in accordance with the } \\
\text { applicable financial reporting framework }\end{array}$ & ISA $700-40$ \\
\hline
\end{tabular}


When International Financial Reporting Standards or International Public Sector

ISA $700-41$

Accounting Standards are not used as the financial reporting framework, the reference to the financial reporting framework in the wording of the opinion should identify the jurisdiction or country of origin of the financial reporting framework

\begin{tabular}{|l|l|}
\hline Other reporting responsibilities & ISA 700-48 \\
\hline Auditor's Signature & ISA 700-50 \\
\hline Date of the Auditor's Report & ISA 700-52 \\
\hline Auditor's Address & ISA 700-57 \\
\hline
\end{tabular}

Appendix 2. Conditional Table of the frequencies of compliance with the revised ISA700 (European auditors' on separate financial and consolidated and consolidated statements)

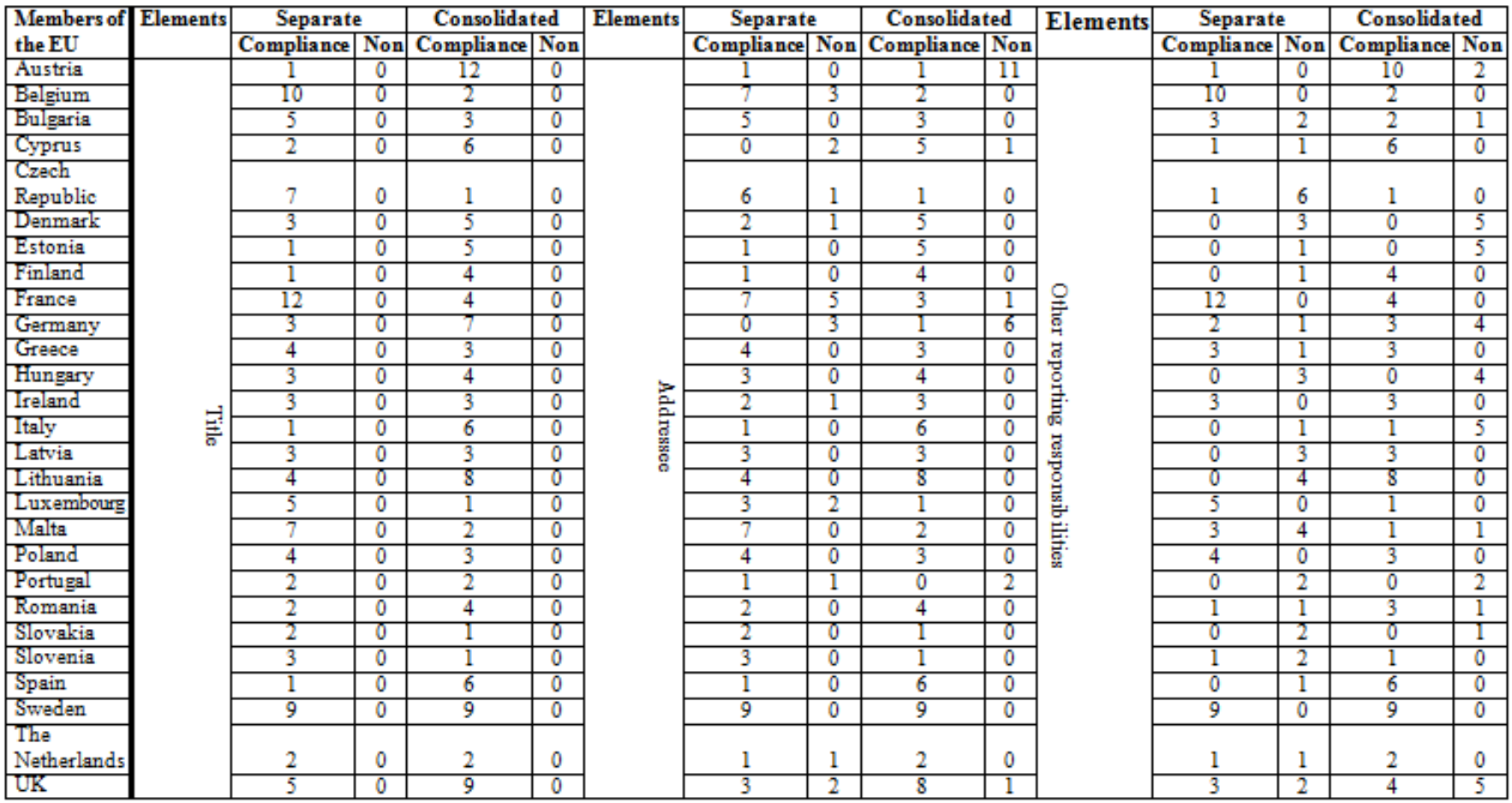


Appendix 2 - continued. Conditional table of the frequencies of compliance with the revised ISA700 (European auditors' on separate financial and consolidated statements)

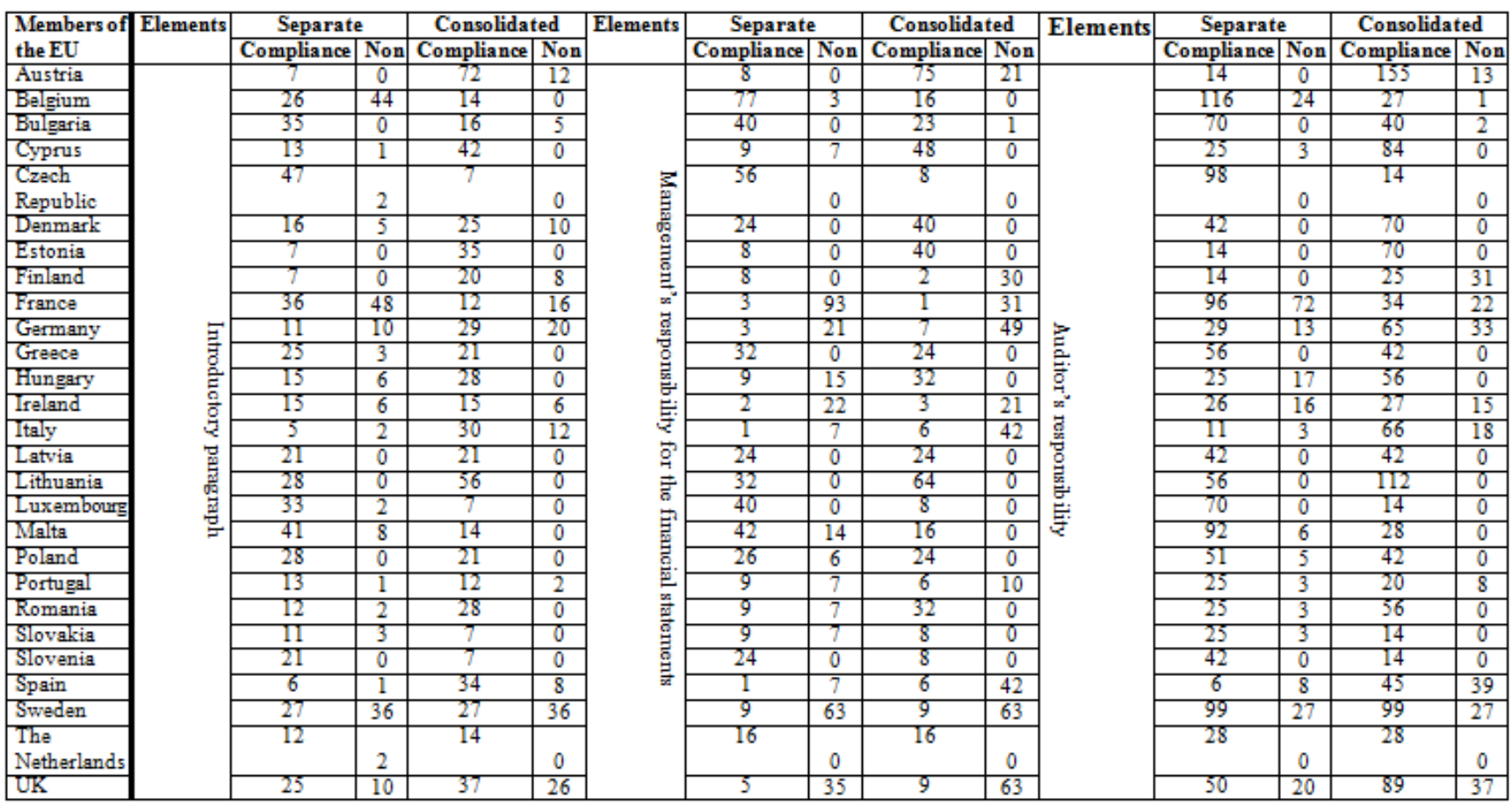

Appendix 2 - continued. Conditional table of the frequencies of compliance with the revised ISA700 (European auditors' on separate financial and consolidated statements)

\begin{tabular}{|c|c|c|c|c|c|c|c|c|c|c|c|c|c|c|c|}
\hline \multirow{2}{*}{$\begin{array}{l}\text { Members of } \\
\text { the EU }\end{array}$} & \multirow[t]{2}{*}{ Elements } & \multicolumn{2}{|c|}{ Separate } & \multicolumn{2}{|c|}{ Consolidated } & \multirow[t]{2}{*}{ Elements } & \multicolumn{2}{|c|}{ Separate } & \multicolumn{2}{|c|}{ Consolidated } & \multirow[t]{2}{*}{ Elements } & \multicolumn{2}{|l|}{ Separate } & \multicolumn{2}{|c|}{ Consolidated } \\
\hline & & \begin{tabular}{|c|} 
Compliance \\
\end{tabular} & Non & \begin{tabular}{|c|} 
Compliance \\
\end{tabular} & Non & & Compliance & Non & Compliance & Non & & Compliance & Non & Compliance & Non \\
\hline Austria & \multirow{28}{*}{ 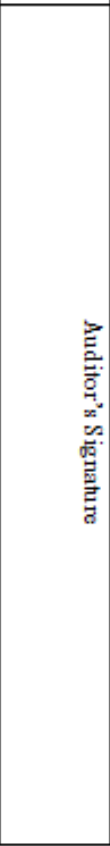 } & 1 & 0 & 12 & 0 & \multirow{28}{*}{ 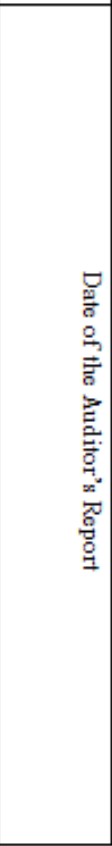 } & 1 & 0 & 12 & 0 & \multirow{28}{*}{ 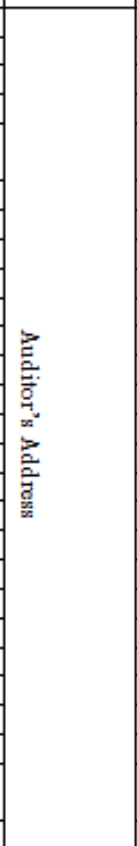 } & 0 & 1 & 0 & 12 \\
\hline Belgium & & 10 & 0 & 2 & 0 & & 10 & 0 & 2 & 0 & & 4 & 6 & 0 & 2 \\
\hline Bulgaria & & 5 & 0 & 3 & 0 & & 5 & 0 & 3 & 0 & & 4 & 1 & 1 & 2 \\
\hline Cyprus & & 2 & 0 & 4 & 2 & & 2 & 0 & 6 & 0 & & 0 & 2 & 2 & 4 \\
\hline $\begin{array}{l}\text { Czech } \\
\text { Republic }\end{array}$ & & 7 & 0 & 1 & 0 & & 7 & 0 & 1 & 0 & & 7 & 0 & 0 & 1 \\
\hline Denmark & & 3 & 0 & 5 & 0 & & 3 & 0 & 4 & 1 & & 0 & 3 & 0 & 5 \\
\hline Estonia & & 1 & 0 & 5 & 0 & & 1 & 0 & 5 & 0 & & 1 & 0 & 5 & 0 \\
\hline Finland & & 1 & 0 & 4 & 0 & & 1 & 0 & 4 & 0 & & 1 & 0 & 0 & 4 \\
\hline France & & 12 & 0 & 4 & 0 & & 10 & 2 & 4 & 0 & & 3 & 9 & 1 & 3 \\
\hline Germany & & 3 & 0 & 7 & 0 & & 3 & 0 & 7 & 0 & & 0 & 3 & 1 & 6 \\
\hline Greece & & 4 & 0 & 3 & 0 & & 4 & 0 & 3 & 0 & & 4 & 0 & 3 & 0 \\
\hline Hungary & & 3 & 0 & 4 & 0 & & 3 & 0 & 4 & 0 & & 3 & 0 & 2 & 2 \\
\hline Ireland & & 3 & 0 & 3 & 0 & & 2 & 1 & 3 & 0 & & 0 & 3 & 0 & 3 \\
\hline Italy & & 1 & 0 & 6 & 0 & & 1 & 0 & 6 & 0 & & 1 & 0 & 6 & 0 \\
\hline Latvia & & 3 & 0 & 3 & 0 & & 3 & 0 & 2 & 1 & & 2 & 1 & 3 & 0 \\
\hline Lithuania & & 4 & 0 & 8 & 0 & & 4 & 0 & 8 & 0 & & 4 & 0 & 8 & 0 \\
\hline Luxembourg & & 5 & 0 & 1 & 0 & & 4 & 1 & 1 & 0 & & 1 & 4 & 1 & 0 \\
\hline Malta & & 7 & 0 & 2 & 0 & & 6 & 1 & 2 & 0 & & 5 & 2 & 1 & 1 \\
\hline Poland & & 4 & 0 & 3 & 0 & & 4 & 0 & 3 & 0 & & 3 & 1 & 3 & 0 \\
\hline Portugal & & 2 & 0 & 2 & 0 & & 2 & 0 & 2 & 0 & & 1 & 1 & 0 & 2 \\
\hline Romania & & 2 & 0 & 4 & 0 & & 2 & 0 & 4 & 0 & & 1 & 1 & 2 & 2 \\
\hline Slovakia & & 2 & 0 & 1 & 0 & & 2 & 0 & 1 & 0 & & 2 & 0 & 1 & 0 \\
\hline Slovenia & & 3 & 0 & 1 & 0 & & 3 & 0 & 1 & 0 & & 0 & 3 & 0 & 1 \\
\hline Spain & & 1 & 0 & 6 & 0 & & 1 & 0 & 6 & 0 & & 1 & 0 & 6 & 0 \\
\hline Sweden & & 9 & 0 & 9 & 0 & & 9 & 0 & 9 & 0 & & 0 & 9 & 0 & 9 \\
\hline The & & & & & & & & & & & & & & & \\
\hline Netherlands & & 2 & 0 & 2 & 0 & & 2 & 0 & 2 & 0 & & 0 & 2 & 0 & 2 \\
\hline UK & & 5 & 0 & 9 & 0 & & 4 & 1 & 9 & 0 & & 1 & 4 & 3 & 6 \\
\hline
\end{tabular}




\section{MInstitute ${ }^{\text {Macrothink }}$}

International Journal of Accounting and Financial Reporting

ISSN 2162-3082

2012, Vol. 2, No. 2

Appendix 2 - continued. Conditional table of the frequencies of compliance with the revised ISA700 (European auditors' on separate and consolidated financial statements)

\begin{tabular}{|c|c|c|c|c|c|c|c|c|c|c|}
\hline \multirow{2}{*}{$\begin{array}{l}\text { Members of the } \\
\text { EU }\end{array}$} & \multirow{2}{*}{ Elements } & \multicolumn{2}{|c|}{ Separate } & \multicolumn{2}{|c|}{ Consolidated } & \multirow[t]{2}{*}{ Elements } & \multicolumn{2}{|c|}{ Separate } & \multicolumn{2}{|c|}{ Consolidated } \\
\hline & & Compliance & Non & Compliance & Non & & Compliance & Non & Compliance & Non \\
\hline Austria & \multirow{27}{*}{ 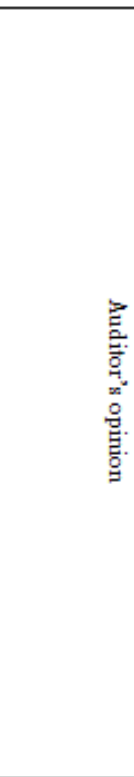 } & 3 & 0 & 36 & 0 & \multirow{27}{*}{ 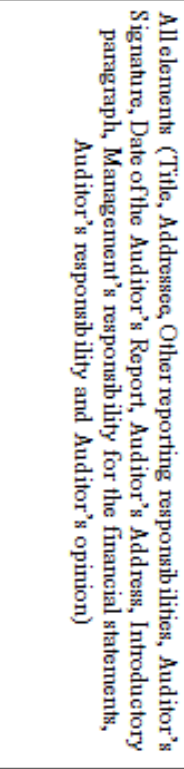 } & 37 & 1 & 385 & 71 \\
\hline Belgium & & 30 & 0 & 6 & 0 & & 300 & 80 & 73 & 3 \\
\hline Bulgaria & & 15 & 0 & 9 & 0 & & 187 & 3 & 103 & 11 \\
\hline Cyprus & & 6 & 0 & 18 & 0 & & 60 & 16 & 221 & 7 \\
\hline Czech Republic & & 21 & 0 & 3 & 0 & & 257 & 9 & 37 & 1 \\
\hline Denmark & & 9 & 0 & 15 & 0 & & 102 & 12 & 169 & 21 \\
\hline Estonia & & 3 & 0 & 15 & 0 & & 37 & 1 & 185 & 5 \\
\hline Finland & & 3 & 0 & 10 & 2 & & 37 & 1 & 77 & 75 \\
\hline France & & 36 & 0 & 12 & 0 & & 227 & 229 & 79 & 73 \\
\hline Germany & & 9 & 0 & 21 & 0 & & 63 & 51 & 148 & 118 \\
\hline Greece & & 12 & 0 & 9 & 0 & & 148 & 4 & 114 & 0 \\
\hline Hungary & & 5 & 4 & 8 & 4 & & 69 & 45 & 142 & 10 \\
\hline Ireland & & 9 & 0 & 9 & 0 & & 65 & 49 & 69 & 45 \\
\hline Italy & & 3 & 0 & 18 & 0 & & 25 & 13 & 151 & 77 \\
\hline Latvia & & 9 & 0 & 9 & 0 & & 110 & 4 & 113 & 1 \\
\hline Lithuania & & 12 & 0 & 24 & 0 & & 148 & 4 & 304 & 0 \\
\hline Luxembourg & & 15 & 0 & 3 & 0 & & 181 & 9 & 38 & 0 \\
\hline Malta & & 19 & 2 & 6 & 0 & & 229 & 37 & 74 & 2 \\
\hline Poland & & 12 & 0 & 9 & 0 & & 140 & 12 & 114 & 0 \\
\hline Portugal & & 5 & 1 & 6 & 0 & & 60 & 16 & 50 & 26 \\
\hline Romania & & 6 & 0 & 12 & 0 & & 62 & 14 & 149 & 3 \\
\hline Slovakia & & 6 & 0 & 3 & 0 & & 61 & 15 & 37 & 1 \\
\hline Slovenia & & 9 & 0 & 3 & 0 & & 109 & 5 & 37 & 1 \\
\hline Spain & & 3 & 0 & 18 & 0 & & 21 & 17 & 139 & 89 \\
\hline Sweden & & 27 & 0 & 27 & 0 & & 207 & 135 & 207 & 135 \\
\hline The Netherlands & & 6 & 0 & 6 & 0 & & 70 & 6 & 74 & 2 \\
\hline UK & & 15 & 0 & 27 & 0 & & 116 & 74 & 204 & 138 \\
\hline
\end{tabular}

Appendix 3. Marginal table of the frequencies of compliance with the revised ISA700 (European auditors' reports on separate and consolidated financial statements)

\begin{tabular}{|c|c|c|c|c|c|c|c|c|c|c|c|c|}
\hline \multirow[t]{2}{*}{$\begin{array}{l}\text { Members of the } \\
\text { EU }\end{array}$} & \multirow[t]{2}{*}{ Elements } & \multicolumn{2}{|c|}{$\begin{array}{l}\text { Separate and } \\
\text { consolidated }\end{array}$} & \multirow[t]{2}{*}{ Elements } & \multicolumn{2}{|c|}{$\begin{array}{l}\text { Separate and } \\
\text { consolidated }\end{array}$} & \multirow[t]{2}{*}{ Elements } & \multicolumn{2}{|c|}{$\begin{array}{l}\text { Separate and } \\
\text { consolidated }\end{array}$} & \multirow[t]{2}{*}{ Elements } & \multicolumn{2}{|c|}{$\begin{array}{l}\text { Separate and } \\
\text { consolidated }\end{array}$} \\
\hline & & Compliance & Non & & Compliance & Non & & Compliance & Non & & Compliance & Non \\
\hline Austria & \multirow{27}{*}{$\bar{\nabla}$} & 13 & 0 & \multirow{27}{*}{ 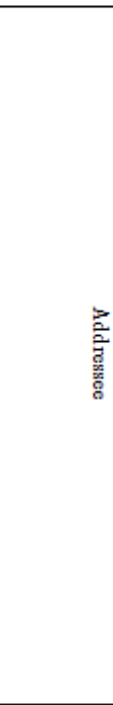 } & 2 & 11 & \multirow{27}{*}{ 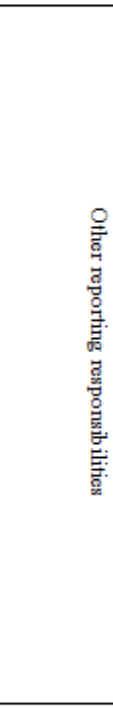 } & 11 & 2 & \multirow{27}{*}{ 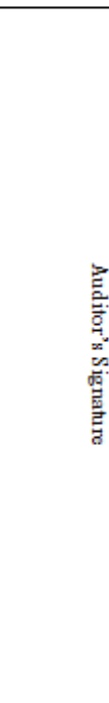 } & 13 & 0 \\
\hline Belgium & & 12 & 0 & & 9 & 3 & & 12 & 0 & & 12 & 0 \\
\hline Bulgaria & & 8 & 0 & & 8 & 0 & & 5 & 3 & & 8 & 0 \\
\hline Cyprus & & 8 & 0 & & 5 & 3 & & 7 & 1 & & 6 & 2 \\
\hline Czech Republic & & 8 & 0 & & 7 & 1 & & 2 & 6 & & 8 & 0 \\
\hline Denmark & & 8 & 0 & & 7 & 1 & & 0 & 8 & & 8 & 0 \\
\hline Estonia & & 6 & 0 & & 6 & 0 & & 0 & 6 & & 6 & 0 \\
\hline Finland & & 5 & 0 & & 5 & 0 & & 4 & 1 & & 5 & 0 \\
\hline France & & 16 & 0 & & 10 & 6 & & 16 & 0 & & 16 & 0 \\
\hline Germany & & 10 & 0 & & 1 & 9 & & 5 & 5 & & 10 & 0 \\
\hline Greece & & 7 & 0 & & 7 & 0 & & 6 & 1 & & 7 & 0 \\
\hline Hungary & & 7 & 0 & & 7 & 0 & & 0 & 7 & & 7 & 0 \\
\hline Ireland & & 6 & 0 & & 5 & 1 & & 6 & 0 & & 6 & 0 \\
\hline Italy & & 7 & 0 & & 7 & 0 & & 1 & 6 & & 7 & 0 \\
\hline Latvia & & 6 & 0 & & 6 & 0 & & 3 & 3 & & 6 & 0 \\
\hline Lithuania & & 12 & 0 & & 12 & 0 & & 8 & 4 & & 12 & 0 \\
\hline Luxembourg & & 6 & 0 & & 4 & 2 & & 6 & 0 & & 6 & 0 \\
\hline Malta & & 9 & 0 & & 9 & 0 & & 4 & 5 & & 9 & 0 \\
\hline Poland & & 7 & 0 & & 7 & 0 & & 7 & 0 & & 7 & 0 \\
\hline Portugal & & 4 & 0 & & 1 & 3 & & 0 & 4 & & 4 & 0 \\
\hline Romania & & 6 & 0 & & 6 & 0 & & 4 & 2 & & 6 & 0 \\
\hline Slovakia & & 3 & 0 & & 3 & 0 & & 0 & 3 & & 3 & 0 \\
\hline Slovenia & & 4 & 0 & & 4 & 0 & & 2 & 2 & & 4 & 0 \\
\hline Spain & & 7 & 0 & & 7 & 0 & & 6 & 1 & & 7 & 0 \\
\hline Sweden & & 18 & 0 & & 18 & 0 & & 18 & 0 & & 18 & 0 \\
\hline The Netherlands & & 4 & 0 & & 3 & 1 & & 3 & 1 & & 4 & 0 \\
\hline UK & & 14 & 0 & & 11 & 3 & & 7 & 7 & & 14 & 0 \\
\hline
\end{tabular}




\section{Macrothink}

International Journal of Accounting and Financial Reporting

ISSN 2162-3082

2012, Vol. 2, No. 2

Appendix 3 - continued. Marginal table of the frequencies of compliance with the revised ISA700 (European auditors' reports on separate and consolidated financial statements)

\begin{tabular}{|c|c|c|c|c|c|c|c|c|c|c|c|c|}
\hline \multirow[t]{2}{*}{$\begin{array}{l}\text { Members of the } \\
\text { EU }\end{array}$} & \multirow[t]{2}{*}{ Elements } & \multicolumn{2}{|c|}{$\begin{array}{l}\text { Separate and } \\
\text { consolidated }\end{array}$} & \multirow[t]{2}{*}{ Elements } & \multicolumn{2}{|c|}{$\begin{array}{l}\text { Separate and } \\
\text { consolidated }\end{array}$} & \multirow[t]{2}{*}{ Elements } & \multicolumn{2}{|c|}{$\begin{array}{l}\text { Separate and } \\
\text { consolidated }\end{array}$} & \multirow[t]{2}{*}{ Elements } & \multicolumn{2}{|c|}{$\begin{array}{l}\text { Separate and } \\
\text { consolidated }\end{array}$} \\
\hline & & Compliance & Non & & Compliance & Non & & Compliance & Non & & Compliance & Non \\
\hline \begin{tabular}{|l|} 
Austria \\
\end{tabular} & \multirow{27}{*}{ 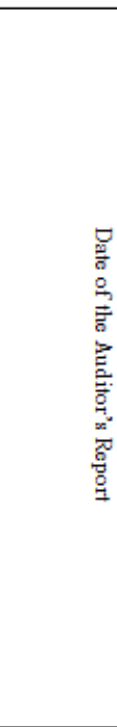 } & 13 & 0 & \multirow{27}{*}{ 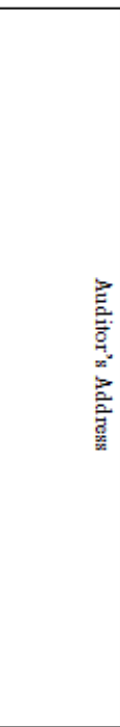 } & 0 & 13 & \multirow{27}{*}{ 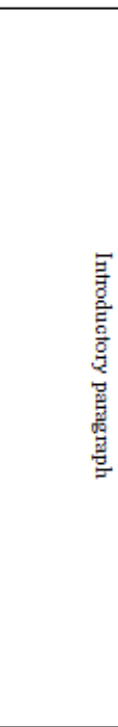 } & 79 & 12 & \multirow{14}{*}{ 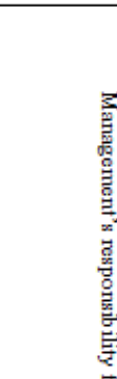 } & 83 & 21 \\
\hline \begin{tabular}{|l|} 
Belgium \\
\end{tabular} & & 12 & 0 & & 4 & 8 & & 40 & 44 & & 93 & 3 \\
\hline Bulgaria & & 8 & 0 & & 5 & 3 & & 51 & 5 & & 63 & 1 \\
\hline Cyprus & & 8 & 0 & & 2 & 6 & & 55 & $T$ & & 57 & 7 \\
\hline Czech Republic & & 8 & 0 & & 7 & 1 & & 54 & 2 & & 64 & 0 \\
\hline Denmark & & 7 & 1 & & 0 & 8 & & 41 & 15 & & 64 & 0 \\
\hline \begin{tabular}{|l|} 
Estonia \\
\end{tabular} & & 6 & 0 & & 6 & 0 & & 42 & 0 & & 48 & 0 \\
\hline Finland & & 5 & 0 & & 1 & 4 & & 27 & 8 & & 10 & 30 \\
\hline France & & 14 & 2 & & 4 & 12 & & 48 & 64 & & 4 & 124 \\
\hline Germany & & 10 & 0 & & 1 & 9 & & 40 & 30 & & 10 & 70 \\
\hline Greece & & 7 & 0 & & 7 & 0 & & 46 & 3 & & 56 & 0 \\
\hline Hungary & & 7 & 0 & & 5 & 2 & & 43 & 6 & & 41 & 15 \\
\hline \begin{tabular}{|l|} 
Ireland \\
\end{tabular} & & 5 & 1 & & 0 & 6 & & 30 & 12 & & 5 & 43 \\
\hline Italy & & 7 & 0 & & 7 & 0 & & 35 & 14 & & 7 & 49 \\
\hline \begin{tabular}{|l|} 
Latvia \\
\end{tabular} & & 5 & 1 & & 5 & 1 & & 42 & 0 & $\vec{g}$ & 48 & 0 \\
\hline \begin{tabular}{|l} 
Lithuania \\
\end{tabular} & & 12 & 0 & & 12 & 0 & & 84 & 0 & $\overrightarrow{\vec{z}}$ & 96 & 0 \\
\hline \begin{tabular}{|l|} 
Luxembourg \\
\end{tabular} & & 5 & 1 & & 2 & 4 & & 40 & 2 & 6 & 48 & 0 \\
\hline Malta & & 8 & 1 & & 6 & 3 & & 55 & 8 & $\mathrm{~F}^{\mathrm{E}}$ & 58 & 14 \\
\hline Poland & & 7 & 0 & & 6 & 1 & & 49 & 0 & हु. & 50 & 6 \\
\hline Portugal & & 4 & 0 & & 1 & 3 & & 25 & 3 & E & 15 & 17 \\
\hline \begin{tabular}{|l} 
Romania \\
\end{tabular} & & 6 & 0 & & 3 & 3 & & 40 & 2 & 运 & 41 & 7 \\
\hline \begin{tabular}{|l} 
Slovakia \\
\end{tabular} & & 3 & 0 & & 3 & 0 & & 18 & 3 & 馬 & 17 & 7 \\
\hline Slovenia & & 4 & 0 & & 0 & 4 & & 28 & 0 & 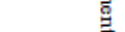 & 32 & 0 \\
\hline Spain & & 7 & 0 & & 7 & 0 & & 40 & 9 & $\overrightarrow{\bar{x}}$ & 7 & 49 \\
\hline Sweden & & 18 & 0 & & 0 & 18 & & 54 & 72 & & 18 & 126 \\
\hline \begin{tabular}{|l} 
The Netherlands \\
\end{tabular} & & 4 & 0 & & 0 & 4 & & 26 & 2 & & 32 & 0 \\
\hline \begin{tabular}{|l|} 
UK \\
\end{tabular} & & 13 & 1 & & 4 & 10 & & 62 & 36 & & 14 & 98 \\
\hline
\end{tabular}

Appendix 3 - continued. Marginal table of the frequencies of compliance with the revised ISA700 (European auditors' reports on separate and consolidated financial statements)

\begin{tabular}{|c|c|c|c|c|c|c|c|c|c|}
\hline \multirow{2}{*}{$\begin{array}{l}\text { Members of the } \\
\text { EU }\end{array}$} & \multirow[t]{2}{*}{ Elements } & \multicolumn{2}{|c|}{ Separate and consolidated } & \multirow[t]{2}{*}{ Elements } & \multicolumn{2}{|c|}{ Separate and consolidated } & \multirow[t]{2}{*}{ Elements } & \multicolumn{2}{|c|}{ Separate and consolidated } \\
\hline & & Compliance & Non & & Compliance & Non & & Compliance & Non \\
\hline Austria & \multirow{27}{*}{ 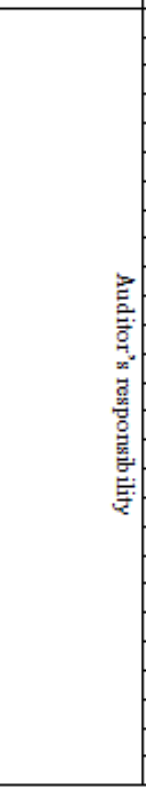 } & 169 & 13 & \multirow{27}{*}{ 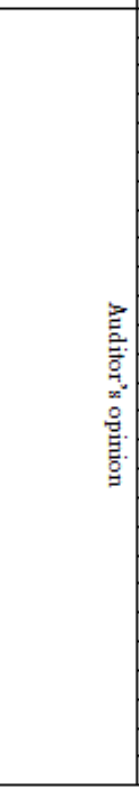 } & 39 & 0 & \multirow{27}{*}{ 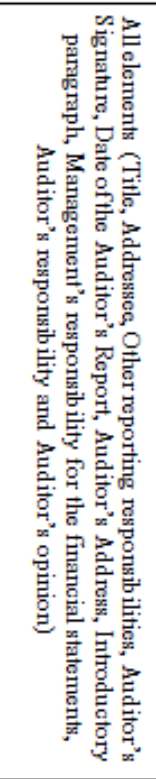 } & 422 & 72 \\
\hline Belgium & & 143 & 25 & & 36 & 0 & & 373 & 83 \\
\hline Bulgaria & & 110 & 2 & & 24 & 0 & & 290 & 14 \\
\hline Cyprus & & 109 & 3 & & 24 & 0 & & 281 & 23 \\
\hline Czech Republic & & 112 & 0 & & 24 & 0 & & 294 & 10 \\
\hline Denmark & & 112 & 0 & & 24 & 0 & & 271 & 33 \\
\hline Estonia & & 84 & 0 & & 18 & 0 & & 222 & 6 \\
\hline Finland & & 39 & 31 & & 13 & 2 & & 114 & 76 \\
\hline France & & 130 & 94 & & 48 & 0 & & 306 & 302 \\
\hline Germany & & 94 & 46 & & 30 & 0 & & 211 & 169 \\
\hline Greece & & 98 & 0 & & 21 & 0 & & 262 & 4 \\
\hline Hungary & & 81 & 17 & & 13 & 8 & & 211 & 55 \\
\hline Ireland & & 53 & 31 & & 18 & 0 & & 134 & 94 \\
\hline Italy & & 77 & 21 & & 21 & 0 & & 176 & 90 \\
\hline Latvia & & 84 & 0 & & 18 & 0 & & 223 & 5 \\
\hline Lithuania & & 168 & 0 & & 36 & 0 & & 452 & 4 \\
\hline Luxembourg & & 84 & 0 & & 18 & 0 & & 219 & 9 \\
\hline Malta & & 120 & 6 & & 25 & 2 & & 303 & 39 \\
\hline Poland & & 93 & 5 & & 21 & 0 & & 254 & 12 \\
\hline Portugal & & 45 & 11 & & 11 & 1 & & 110 & 42 \\
\hline Romania & & 81 & 3 & & 18 & 0 & & 211 & 17 \\
\hline Slovakia & & 39 & 3 & & 9 & 0 & & 98 & 16 \\
\hline Slovenia & & 56 & 0 & & 12 & 0 & & 146 & 6 \\
\hline Spain & & 51 & 47 & & 21 & 0 & & 160 & 106 \\
\hline Sweden & & 198 & 54 & & 54 & 0 & & 414 & 270 \\
\hline The Netherlands & & 56 & 0 & & 12 & 0 & & 144 & 8 \\
\hline UK & & 139 & 57 & & 42 & 0 & & 320 & 212 \\
\hline
\end{tabular}

